\title{
Efficient Electronic Communication of Two Ruthenium Centers through a Rigid Ditopic N-Heterocyclic Carbene Linker
}

Michael Nussbaum, ${ }^{[\mathrm{a}]}$ Oliver Schuster, ${ }^{*[\mathrm{a}]}$ Martin Albrecht*[a,b]

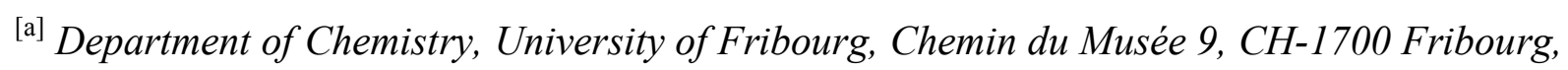
Switzerland

${ }^{[b]}$ School of Chemistry \& Chemical Biology, University College Dublin, Belfield, Dublin 4, Ireland.

Fax:+35317162501; Phone:+35317162504; E-mail: martin.albrecht@ucd.ie

Abstract. A ditopic benzobis(carbene) ligand precursor was prepared that contained a chelating pyridyl moiety to ensure co-planarity of the carbene ligand and the coordination plane of a bound octahedral metal center. Bimetallic ruthenium complexes comprising this ditopic ligand $\mathrm{L}_{4} \mathrm{Ru}-C, N-$ bbi-C,N-RuL 4 were obtained by a transmetalation methodology ( $C, N$-bbi-C, $N=$ benzobis $(N$-pyridyl- $N$ '-methyl-imidazolylidene). The two metal centers are electronically decoupled when the ruthenium is in a pseudo-tetrahedral geometry imparted by a cymene spectator ligand $\left(\mathrm{L}_{4}=[(\mathrm{cym}) \mathrm{Cl}]\right)$. Ligand exchange of the $\mathrm{Cl}^{-}$/cymene ligands for two bipyridine or four $\mathrm{MeCN}$ ligands induced a change of the coordination geometry to octahedral. As a consequence, the ruthenium centers, separated through space by more than $10 \AA$, become electronically coupled, which is evidenced by two distinctly different metalcentered oxidation processes that are separated by $134 \mathrm{mV}\left(\mathrm{L}_{4}=\left[(\text { bpy })_{2}\right]\right)$ and $244 \mathrm{mV}\left(\mathrm{L}_{4}=\right.$ $\left.\left[(\mathrm{MeCN})_{4}\right]\right)$, respectively. Hush analysis of the intervalence charge transfer bands in the mixed-valent species indicates substantial valence delocalization in both complexes (delocalization parameter $\Gamma=0.41$ and 0.37 in the bpy and $\mathrm{MeCN}$ complexes, respectively). Spectroelectrochemical measurements further indicated that the mixed-valent $\mathrm{Ru}^{\mathrm{II}} / \mathrm{Ru}^{\mathrm{III}}$ species and the fully oxidized $\mathrm{Ru}^{\mathrm{III}} / \mathrm{Ru}^{\mathrm{III}}$ complexes gradually decompose when bound to $\mathrm{MeCN}$ ligands, while the bpy spectators significantly enhance the stability. These results demonstrate the efficiency of carbenes and in particular of the bbi ligand scaffold for mediating electron transfer and for the fabrication of molecular redox switches. Moreover, the relevance of spectator ligands is emphasized for tailoring the degree of electronic communication through the benzobis(carbene) linker. 


\section{Introduction}

Molecular switches provide intriguing opportunities as active entities for the storage and processing of data. ${ }^{[1]}$ Metal complexes are particularly attractive units for such switching purposes, since they offer multiple read-out functions due to their potential activity in noninvasive events such as reversible redox, ${ }^{[2]}$ spin transitions, ${ }^{[3]}$ and charge transfer ${ }^{[4]}$ processes. The resulting electronic, magnetic and optical signals constitute a diagnostic probe for the state of the switch. ${ }^{[1-4]}$ The information density can be considerably enhanced when metal centers are mutually coupled. For example, redox switching of a bimetallic species gives access to a stable mixed-valent state in addition to the fully oxidized and reduced states, if the metal centers are electronically coupled. ${ }^{[5]}$ Such mixed-valent states have distinct properties that depend on the degree of coupling. ${ }^{[6]}$ A valence-localized system will thus provide access to a molecular diode with the oxidized entity as acceptor and the reduced unit as donor site. ${ }^{[7]}$ Valence-delocalized systems will be excellent constituents of molecular wires ${ }^{[8]}$ with the possibility for tailoring activity through modification of the bridging ligand.

Intramolecular metal-metal coupling is critically dependent on the ability of the bridging ligand to function as an electronic relay. ${ }^{[9]}$ The two currently most popular classes of ligands that promote coupling in bimetallic systems are comprised of either ditopic bi- and oligopyridines, ${ }^{[10]}$ and of oliogacetylenes. ${ }^{[1]}$ While the latter type of ligands offers an excellent electronic link between the metal and the bridging ligand with a high degree of $\mathrm{d}_{\mathrm{M}^{-}}$ $\pi_{\mathrm{L}}$ overlap, especially in metal-alkylidene and metal-alkynylidene oxidation states, the oligopyridine family dwells on the $\pi$-acidity of the chelating pyridyl ligand and its synthetic versatility for functionalization. In a simplistic view, N-heterocyclic carbenes $(\mathrm{NHCs})^{[12]}$ represent a fusion of these two successful classes of ligands, featuring the synthetic versatility $^{[13]}$ of pyridines with the (partial) $\pi$ component of the $\mathrm{M}-\mathrm{C}_{\mathrm{NHC}}$ bond ${ }^{[14]}$ reminiscent of acetylenes. Stimulated by these considerations, a variety of ditopic NHC ligands have been developed (e.g. A-C, Fig. 1). ${ }^{[15]}$ However, even in complexes containing the apparently highly conjugated benzobis(imidazolylidene) bridging ligand $\mathbf{C}$, the metal-metal interaction was mediocre at best. Different explanations for the weak coupling of the metal centers in this molecular configuration have been put forward, ${ }^{[16]}$ including low $\mathrm{d}_{\mathrm{M}}-\mathcal{\pi}_{\mathrm{L}}$ overlap due to a mismatch of the ligand $2 \mathrm{p}$ orbital and the metal $4 \mathrm{~d}$ orbitals, ${ }^{[17]}$ poor $\pi$ electron delocalization between the arene and the NCN units in the bridging ligand, ${ }^{[18]}$ and an unfavorable orientation of the relevant $d_{M}$ orbitals with respect to the $\pi_{L}$ system that mimizes overlap. ${ }^{[19]}$ We have addressed this latter issue by incorporating rigid pyridyl donor groups into the NHC wingtips, 
which induce chelation and consequentially impart a coaxial arrangement of the metal and ligand orbitals, a concept that has been widely exploited in bipyridine chemistry. ${ }^{[20]}$ The constrained NHC coordination substantially enhances the intermetallic coupling between two ruthenium centers bridged by ligands of type $\mathbf{C}$. The electronic $\mathrm{Ru}$... Ru coupling is critically dependent on the nature of the spectator ligands and on the coordination geometry they impose. These results indicate that appropriately designed dicarbenes provide efficient bridging ligands for the fabrication of molecular switches, and they emphasize the relevance of the mutual orientation of ligand and metal orbitals.
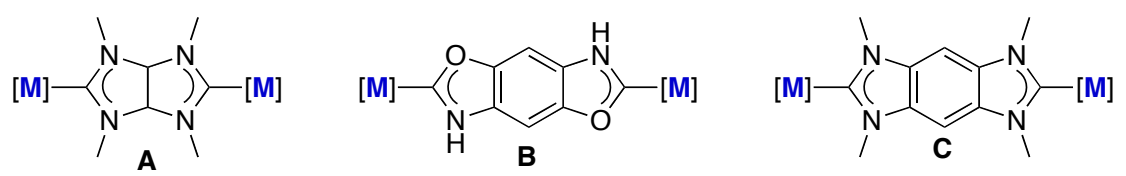

Fig 1. Relevant examples of ditopic NHC ligands.

\section{Results and discussion}

Synthesis of ditopic pyridyl-carbene precursor and dimetallic $R u_{2}$ complexes. The synthetic approach towards chelating dicarbene ligands containing pyridyl donor groups was inspired by a methodology developed by Bielawski and coworkers for related monodentate ligand platforms (Scheme 1). ${ }^{[21]}$ Accordingly, amination of 2,4-dinitro-1,5-dichlorobenzene with 2-aminopyridine furnished the pyridyl-functionalized product $\mathbf{1}$. Aminations performed in EtOH at $120{ }^{\circ} \mathrm{C}$ afforded $\mathbf{1}$ only after extended reaction times and furnished monosubstituted compounds as major products due presumably to the deactivating effect of the first pyridyl substituent. Yields and purity were substantially higher in a solvent-free reaction using a large excess of 2 -aminopyridine at $90^{\circ} \mathrm{C}$. Subsequent heterocycle formation was achieved in a palladium-catalyzed one-pot reaction involving reduction of the nitro groups with formic acid followed by in situ cyclization with orthoformate, which afforded the pyridyl-substituted benzobis(imidazole) 2. Cyclization induced a marked upfield shift of the aryl proton resonances from $\delta_{\mathrm{H}} 9.38$ and 10.26 in $\mathbf{1}$ to 8.32 and $8.92 \mathrm{ppm}$ in $\mathbf{2}$. Moreover, a singlet at $\delta_{\mathrm{H}} 8.62 \mathrm{ppm}$ was attributed to the imidazole proton $\left(\delta_{\mathrm{C}} 142.2 \mathrm{ppm}\right)$. The reaction proceeds in high yields $(>80 \%)$. The largest side product was identified by HPLC-MS $(\mathrm{m} / \mathrm{z}$ $357 \mathrm{~g} \mathrm{~mol}^{-1}$ ) as an ethoxy-adduct of 2 , possibly originating from incomplete EtOH elimination upon cyclization with $\mathrm{HC}(\mathrm{OEt})_{3}$. Formation of $\mathbf{2}$ was unambiguously confirmed 
by an X-ray crystal structure determination (Fig. S1), which revealed an essentially planar molecular structure for $\mathbf{2}$. The central benzene ring is elongated along the $\mathrm{CH}$... $\mathrm{CH}$ vector, a feature that was previously observed by Bielawski ${ }^{[\mathrm{xx}]}$ and $u s,{ }^{[\mathrm{xx}]}$ albeit in a less pronounced manner. Pairs of molecules of $\mathbf{2}$ are stacked along the crystallographic c-axis and give rise to supramolecular zig-zag layers in the a-b plane (Fig. S1).

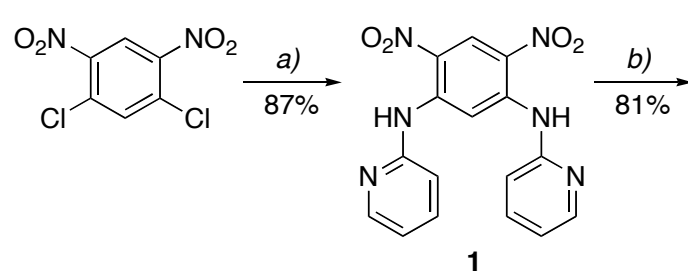

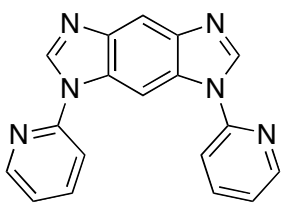

2
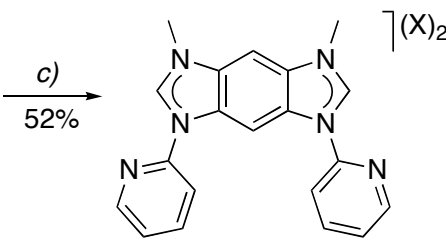

$3(\mathrm{X}=\mathrm{I})$
$4\left(\mathrm{X}=\mathrm{PF}_{6}\right) \longleftarrow \begin{aligned} & d) \\ & 87 \%\end{aligned}$

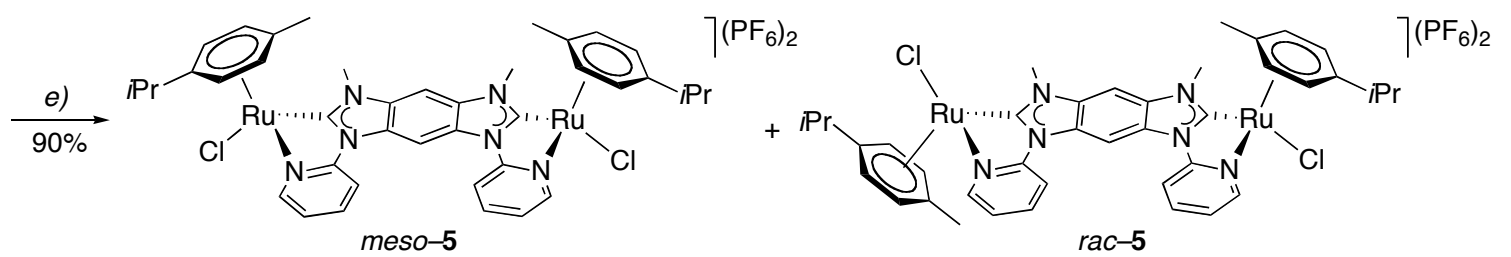

Scheme 1. Synthesis of complexes 5. Reagents and conditions: a) 2- $\mathrm{NH}_{2}$-pyridine, $90{ }^{\circ} \mathrm{C}, 3 \mathrm{~d}$; b) $\mathrm{HCOONa}$, $\mathrm{HCOOH}, \mathrm{Pd} / \mathrm{C}, \mathrm{HC}(\mathrm{OEt})_{3}, 100{ }^{\circ} \mathrm{C}, 36 \mathrm{~h}$; c) MeI, MeCN, microwave irradiation, $110^{\circ} \mathrm{C}, 1 \mathrm{~h}$; d) $\left(\mathrm{NH}_{4}\right) \mathrm{PF}_{6}, \mathrm{H}_{2} \mathrm{O}$; e) $\mathrm{Ag}_{2} \mathrm{O}, \mathrm{MeOH}, 24 \mathrm{~h}$, then $\left[\mathrm{RuCl}_{2} \text { (p-cymene) }\right]_{2}, \mathrm{CH}_{2} \mathrm{Cl}_{2}, 3$ d; f) $\mathrm{AgPF}_{6}, \mathrm{MeCN}$, reflux, $20 \mathrm{~h}$ (52\%); g) 2,2'bipyridine, $\mathrm{MeNO}_{2}$, reflux, $20 \mathrm{~h}$.

The benzobis(imidazole) was selectively quaternized with excess MeI to yield the benzobis(imidazolium) salt 3. The substantial downfield shift of the NCHN proton (from $\delta_{\mathrm{H}}$ 8.62 to $10.84 \mathrm{ppm}$ ) and to a lesser extent of the aryl protons ( $\Delta \delta \mathrm{ca} .0 .8 \mathrm{ppm}$ ) in the ${ }^{1} \mathrm{H}$ NMR spectrum supports alkylation of the imidazole unit. Moreover, the NMR resonances of the pyridyl fragment are essentially unaltered upon alkylation, indicating that imidazole methylation is selective. Anion exchange with aqueous $\left(\mathrm{NH}_{4}\right) \mathrm{PF}_{6}$ gave 4 and was carried out to avoid issues due to potential halide scrambling in the subsequent (trans)metallation step.

Complexation of the ditopic carbene precursor was accomplished according to a classical metalation-transmetalation protocol using $\mathrm{Ag}_{2} \mathrm{O}$ and $\left[\mathrm{RuCl}_{2}\left(\eta^{6} \text {-p-cymene }\right)\right]_{2} \cdot{ }^{[22]}$ While the transruthenation afforded pure products when performed in $\mathrm{CH}_{2} \mathrm{Cl}_{2}$, reaction with $\mathrm{Ag}_{2} \mathrm{O}$ in this solvent was exceedingly slow, presumably due to the limited solubility of the dicationic salt 4. Therefore, formation of the carbene silver intermediate was performed in $\mathrm{MeOH}$ and the solvent was then changed to $\mathrm{CH}_{2} \mathrm{Cl}_{2}$ for the transmetalation, without any purification or characterization of the probably polymeric silver complex. ${ }^{[23]}$ Complex $\mathbf{5}$ is an air stable orange solid. While HPLC-MS suggests a pure compound, NMR analysis shows two distinct sets of signals that were attributed to the rac and meso diastereoisomers of $\mathbf{5}$ as a consequence 
of the chirality of the complex at each ruthenium center. ${ }^{[15,24]}$ Solubility tests revealed that one of the two isomers is less soluble in $\mathrm{MeCN}$ and was thus successfully separated by repetitive precipitation and filtration. This isomer is stable in solution over several days, demonstrating that racemization at ruthenium is very slow. Hence, 2D NMR measurements allowed all resonances to be assigned to one or the other isomer. However, we were unable to confidently assign the meso and rac designations based on spectroscopic data, and crystallization attempts have failed to date.

Successful double metalation was indicated by the pertinent cymene/benzobis(carbene) integral ratios and by the carbenic resonance at $\delta_{\mathrm{C}} 202.8$ and $203.3 \mathrm{ppm}$, corresponding to more than 50 ppm downfield shift compared to the ligand precursor (Table 1). As expected for a chiral complex, all four aromatic cymene protons are magnetically inequivalent, and the $i$ Pr group appears as two distinct high field doublets for each isomer. Chelation of the pyridyl group is supported by the marked deshielding of the C6-bound pyridyl protons $(\Delta \delta>0.4$ $\mathrm{ppm})$. Moreover, the resonances of the protons of the central arene ring experience a diagnostic upfield shift upon ruthenation and appear at $\delta_{\mathrm{H}} 7.84$ and $7.69 \mathrm{ppm}$ in one isomer, and at $\delta_{\mathrm{H}} 8.20$ and $8.56 \mathrm{ppm}$ in the other one $\left(c f \delta_{\mathrm{H}} 9.08\right.$ and $9.65 \mathrm{ppm}$ in the ligand precursor 4). These shift differences suggest a strong electronic coupling of the metal center with the central arene moiety.

Table 1. Selected NMR shifts of complexes 5-7 and the ligand precursor $4^{\text {a) }}$

\begin{tabular}{cccccc}
\hline Compound & $\delta_{\mathrm{C}} \mathrm{NCN}$ & $\delta_{\mathrm{H}} \mathrm{H}_{\mathrm{Ar}}$ & $\delta_{\mathrm{C}} \mathrm{C}_{\mathrm{Ar}}-\mathrm{H}$ & $\delta_{\mathrm{H}} \mathrm{H}_{\mathrm{Ar}}$, & $\delta_{\mathrm{C}} \mathrm{C}_{\mathrm{Ar}}$ \\
\hline $\mathbf{4}$ & 146.7 & 9.65 & 103.6 & 9.08 & 99.7 \\
$\mathbf{5}$ & 203.3 & 8.56 & 97.8 & 8.20 & 96.7 \\
$\mathbf{5}$ & 202.8 & 7.84 & 95.9 & 7.69 & 95.9 \\
$\mathbf{6}$ & 207.6 & 8.58 & 95.9 & 8.11 & 94.8 \\
$\mathbf{7}$ & 211.1 & 8.92 & 96.2 & 7.69 & 93.7 \\
\hline
\end{tabular}

a) all data in $\mathrm{CDCl}_{3}$ except 4 (in DMSO- $\mathrm{d}_{6}$ ); Ar denotes the position $\beta$ to the pyridyl-substituted nitrogen, Ar' the position $\beta$ to the methyl-substituted nitrogen atom; $\mathbf{5}$ and $\mathbf{5}$ ' are the two diastereoisomers of $\mathbf{5}$ (meso and rac).

Substitution of the ancillary ligands was achieved according to established procedures. ${ }^{[25]}$ Thus, reaction of complex 5 with $\mathrm{AgPF}_{6}$ in $\mathrm{MeCN}$ at reflux temperature gave the solvento complex 6 (Scheme 2). The reaction progress is conveniently monitored optically as the bright orange solution turns colorless upon displacement of the $\mathrm{Cl}^{-}$and cymene ligands. The NMR spectra of complex 6 reveal only one set of signals and thus support the notion of diastereomeric mixtures in 5. Evidently, the ruthenium centers are achiral in $\mathbf{6}$. The carbene carbon is further deshielded (from $\delta_{\mathrm{C}} 203$ to $207.6 \mathrm{ppm}$ ), and also the central arene protons 
undergo a slight downfield shift, $\delta_{\mathrm{H}} 8.11$ and $8.58 \mathrm{ppm}$. Three different types of $\mathrm{MeCN}$ ligands are resolved, with one set $\left(\delta_{\mathrm{H}} 2.09 \mathrm{ppm}\right)$ twice as intense as the other two sets $\left(\delta_{\mathrm{H}} 2.60\right.$ and $1.96 \mathrm{ppm}$, respectively). These features support an octahedral coordination geometry of the ruthenium centers with two $\mathrm{MeCN}$ in mutual trans position and hence symmetry-related. Based on the stronger donor properties of NHCs vs pyridine ligands, the most deshielded resonance was tentatively attributed to the $\mathrm{MeCN}$ ligand trans to the pyridyl donor and the resonance at highest field to the $\mathrm{MeCN}$ trans to the carbene.

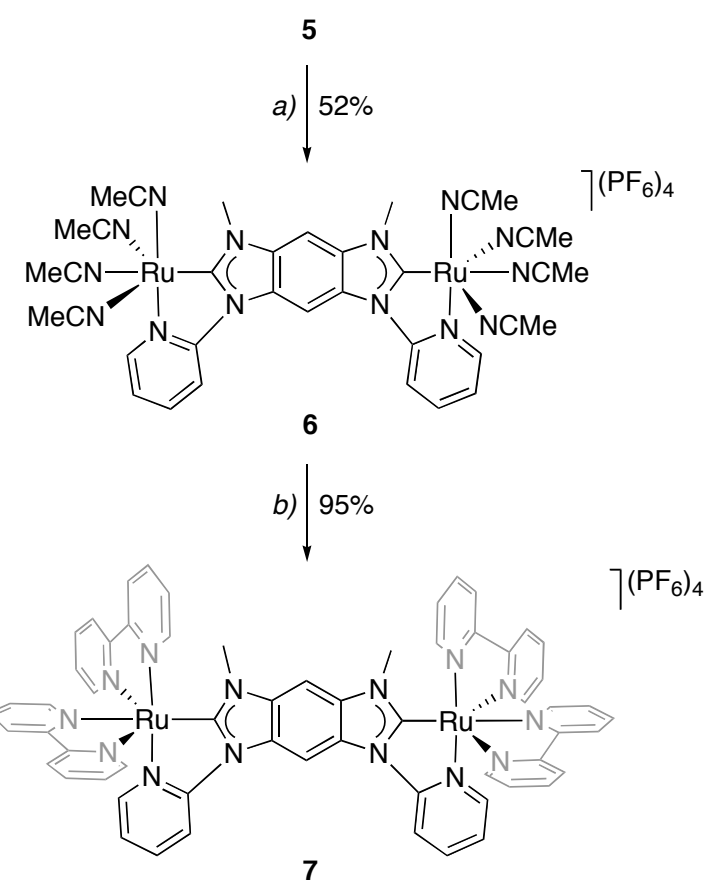

Scheme 2. Synthesis of complexes 6 and 7. Reagents and conditions: a) $\mathrm{AgPF}_{6}, \mathrm{MeCN}$, reflux, $20 \mathrm{~h}$; b) 2,2'bipyridine, $\mathrm{MeNO}_{2}$, reflux, $20 \mathrm{~h}$.

Crystals of 6 suitable for an X-ray diffraction analysis were obtained by slow diffusion of $\mathrm{Et}_{2} \mathrm{O}$ into a $\mathrm{MeCN}$ solution of the complex. The molecular structure (Fig. 2) confirms the octahedral geometry of the two ruthenium centers, with only little angular distortion. The bite angle of the $C, N$-bidentate ligand is $78.5(4)^{\circ}$, which is in line with related structures featuring pyridyl-substituted NHC ligands. ${ }^{[26]}$ As a consequence of this acute bite angle, the overall molecular shape of 6 is curved. ${ }^{[27]}$ The $\mathrm{Ru}-\mathrm{N}$ bonds for the MeCN ligands trans to the carbenes (2.115(6) $\AA$ and 2.113(6) $\AA$ ) are significantly longer than the remaining $\mathrm{Ru}-\mathrm{N}$ distances (2.02-2.04 $\AA$, Table 1). This elongation is in agreement with a substantially stronger trans influence of the carbene ligand, which is often correlated with its strong $\sigma$-donor ability. The metal-metal separation in 6 is 10.537(2) $\AA$ and hence some $0.2 \AA$ shorter than the $\mathrm{Ru} . . \mathrm{Ru}$ distance in a bimetallic complex with an analogous ditopic ligand that lacks 
chelating wingtip groups. ${ }^{[18]}$ This difference is almost fully accounted for by the shorter $\mathrm{Ru}-\mathrm{C}$ bond upon chelation, viz. 1.95(1) $\AA$ in 6 vs 2.065(4) $\AA$ in the monodentate analogue.

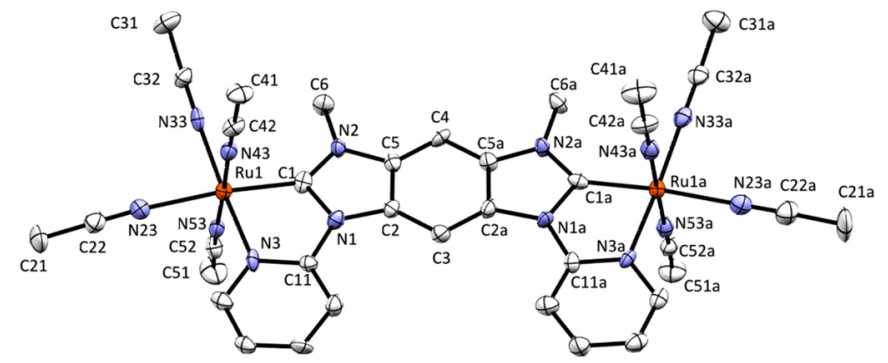

Figure 2. ORTEP view of complex 6 (50\% probability ellipsoids; Hydrogen atoms, counter-ions and cocrystallized MeCN molecules omitted for clarity).

Table 2. Selected bond lengths $(\AA)$ and angles $\left(^{\circ}\right)$ for complexes $\mathbf{6}$, and $\mathbf{1 0}$.

\begin{tabular}{llll}
\hline & & $6^{\text {a) }}$ & $\mathbf{1 0}$ \\
\hline $\mathrm{Ru} 1-\mathrm{C} 1$ & $1.955(6)$ & $1.945(6)$ & $1.979(4)$ \\
$\mathrm{Ru} 1-\mathrm{N} 3$ & $2.053(6)$ & $2.059(6)$ & $2.068(5)$ \\
$\mathrm{Ru} 1-\mathrm{N} 23$ & $2.115(6)$ & $2.113(6)$ & $2.126(3)$ \\
$\mathrm{Ru} 1-\mathrm{N} 33$ & $2.042(6)$ & $2.038(6)$ & $2.046(6)$ \\
$\mathrm{Ru} 1-\mathrm{N} 43$ & $2.034(6)$ & $2.025(6)$ & $2.074(5)$ \\
$\mathrm{Ru} 1-\mathrm{N} 53$ & $2.026(6)$ & $2.022(6)$ & $2.062(6)$ \\
& & & \\
$\mathrm{C} 1-\mathrm{N} 1$ & $1.388(9)$ & $1.393(9)$ & $1.393(8)$ \\
$\mathrm{C} 1-\mathrm{N} 2$ & $1.346(9)$ & $1.380(8$ & $1.350(7)$ \\
$\mathrm{N} 1-\mathrm{C} 2$ & $1.346(9)$ & $1.413(8)$ & $1.416(5)$ \\
$\mathrm{N} 2-\mathrm{C} 5$ & $1.395(8)$ & $1.368(9)$ & $1.413(6)$ \\
$\mathrm{N} 1-\mathrm{C} 1-\mathrm{N} 2$ & $105.2(6)$ & $105.0(6)$ & $104.2(5)$ \\
$\mathrm{C} 1-\mathrm{N} 1-\mathrm{C} 11$ & $116.2(6)$ & $116.7(6)$ & $117.3(5)$ \\
$\mathrm{C} 1-\mathrm{Ru} 1-\mathrm{N} 3$ & $78.4(3)$ & $78.5(3)$ & $77.7(2)$ \\
& & & \\
$\mathrm{C} 1 \cdots \mathrm{C} 1 \mathrm{a}$ & $6.690(8)$ & $6.690(8)$ & --- \\
$\mathrm{Ru}{ }^{*} \mathrm{Ru}$ & $10.537(2)$ & $10.537(2)$ & --- \\
\hline
\end{tabular}

a) right column pertains to east end of the complex (a labels in Fig 2).

Subsequent ligand exchange with 2,2'-bipyridine (bpy) was straightforward in $\mathrm{MeNO}_{2}$ and yielded bright orange complex 7 in excellent yield (90\%). Introduction of bpy directly starting from the cymene complex 5 in the presence of $\mathrm{AgPF}_{6}$ was less successful and afforded a mixture of compounds containing both bipyridine and $\mathrm{MeCN}$ ligands bound to the ruthenium center. The NMR data of complex 7 indicate the presence of two diastereoisomers, however, the congestion of the aromatic region due to the presence of two sets of 5 inequivalent pyridyl fragments did not allow proton and carbon resonances to be fully resolved and unambiguously assigned. Most diagnostic are the shielding of the pyridyl proton in $\alpha$ position as well as a shift of the carbene resonance to higher field ( $\left.\delta_{\mathrm{C}} 211.1 \mathrm{ppm}\right)$. In addition, the 
chemical shift difference between the two central arene protons increases upon bpy coordination. The two resonances appear in complex 7 at $\delta_{\mathrm{H}} 7.69$ and $8.92 \mathrm{ppm}$ and are thus some $1.2 \mathrm{ppm}$ apart, while $\Delta \delta<0.5 \mathrm{ppm}$ in $\mathbf{6}$. Again, the sensitivity of these central protons towards peripheral ligand exchange reactions suggests that electronic coupling of the metal center with these protons and hence with the center of the molecule is effective.

Synthesis of Monocarbene Complexes. For comparative purposes, analogous monometallic complexes were prepared via a route similar to the synthesis of the bimetallic complexes 5-7. Thus, stirring of complex $\mathbf{8}^{[25]}$ at reflux temperature in $\mathrm{MeCN}$ in the presence of $\mathrm{AgPF}_{6}$ gave the solvento complex $\mathbf{9}$ and subsequent addition of bpy yielded complex $\mathbf{1 0}$ as monometallic analogue of 7 (Scheme 3). Similar spectroscopic trends as deduced for the bimetallic complexes were observed. For example, the resonance of the carbene nucleus gradually shifts upfield upon introducing MeCN and subsequently bpy spectator ligands $\left(\delta_{\mathrm{C}} 198.2,204.0\right.$, and 207.9 for $\mathbf{8}$, 9, and 10, respectively). Moreover, four coordinated $\mathrm{MeCN}$ molecules were spectroscopically identified in $\mathbf{9}$ in the 1:2:1 ratio as discussed for the bimetallic complex 6 (see above).

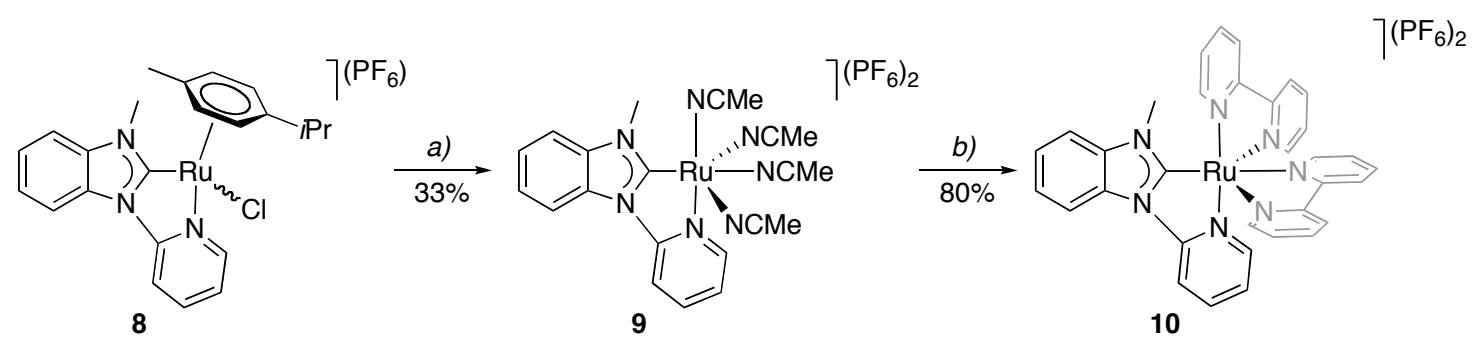

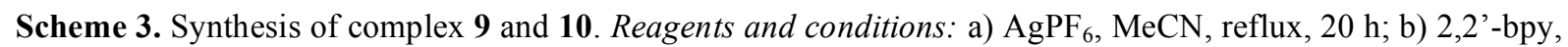
$\mathrm{MeNO}_{2}$, reflux, $20 \mathrm{~h}$.

Crystals of 9 featured severe disorder in co-crystallized solvent molecules and $\mathrm{PF}_{6}{ }^{-}$anions, which prevented refinement to an acceptable convergence. Hence, discussion of structural data of the cationic section is limited (Fig. S2). Crystals of 10 (Fig. 3) were of better quality. The molecular structure confirms the expected connectivity pattern. The $\mathrm{Ru}-\mathrm{C}$ bond (1.979(4) $\AA$ ) and the $\mathrm{Ru}-\mathrm{N}_{\text {pyridine }}$ bond (2.068(5) $\AA$ ) are slightly longer than in 6, and consequentially, the bite angle is more acute, $77.7(2)^{\circ}$. As in $\mathbf{6}$ and $\mathbf{9}$, the carbene exerts the strongest trans influence and the Ru-N23 bond trans to the NHC moiety is significantly longer (2.126(3) $\AA$ ) compared to the other $\mathrm{Ru}-\mathrm{N}_{\text {pyridine }}$ bonds $(2.046(6)-2.074(5) \AA)$. 


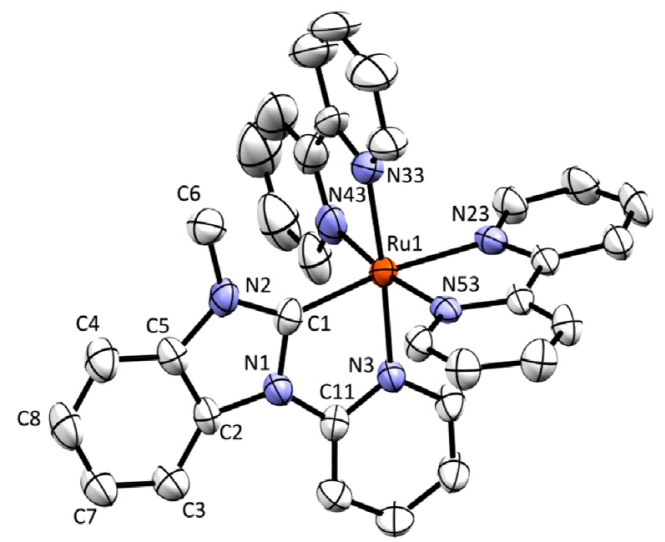

Figure 3. ORTEP view of $\mathbf{1 0}$ (50\% probability ellipsoids; hydrogen atoms and non-coordinating $\mathrm{PF}_{6}^{-}$anions omitted for clarity).

Electrochemical Analyses. Cyclovoltammetry (CV) measurements of complex $\mathbf{5}$ in $\mathrm{CH}_{2} \mathrm{Cl}_{2}$ show a single and reversible oxidation/reduction process with $E_{1 / 2}\left(\mathbf{5}^{\mathbf{2}} / \mathbf{5}\right)=+1.606 \mathrm{~V} v s \mathrm{SCE}$ (Fig. S3, Table 3). This redox potential is about $0.5 \mathrm{~V}$ higher than that of neutral $\left[\mathrm{Ru}(\mathrm{cym})(\mathrm{NHC}) \mathrm{Cl}_{2}\right]$ complexes $^{[18]}$ and thus demonstrates the lower electron density in the cationic chelates, which is also reflected in the NMR deshielding of the ligand protons (see above). No further oxidation occurred up to $+1.9 \mathrm{~V}$. The cathodic current of the oxidation was considerably larger than the anodic current. Such behavior has previously been attributed to the adsorption of the oxidized analyte to the electrode surface. ${ }^{[28]}$ In contrast, the corresponding monometallic complex $\mathbf{8}$ shows no such adsorption effect, but a similar $E_{1 / 2}$ $\left(\mathbf{8}^{+} / \mathbf{8}\right)=+1.583$ V. Differential pulse voltammetry (DPV) measurements did not show any substantial broadening of the signal recorded for $\mathbf{5}$ compared to that of the monometallic analogue $\mathbf{8}$, indicating that the two metal centers in $\mathbf{5}$ are essentially decoupled (Class-I according to Robin and Day). ${ }^{[29]}$ Measurements in $\mathrm{MeCN}$ or $\mathrm{MeNO}_{2}$ were inconclusive and showed either an irreversible oxidation $(\mathrm{MeCN})$, or no redox-process at all $\left(\mathrm{MeNO}_{2}\right)$. Displacement of the chloride ligand may account for the different behavior of $\mathbf{5}$ and $\mathbf{8}$ in these solvents as compared to $\mathrm{CH}_{2} \mathrm{Cl}_{2}$.

Table 3. Electrochemical data for complexes 5-10. ${ }^{\text {a) }}$

\begin{tabular}{llllccc}
\hline \multicolumn{2}{c}{ Complex } & solvent & $E_{1 / 2} / \mathrm{V}$ & $\Delta E / \mathrm{mV}^{\mathrm{b})}$ & $\Delta E_{1 / 2} / \mathrm{mV}$ & $K_{\mathrm{c}}{ }^{\mathrm{c}}$ \\
\hline $\mathbf{5}$ & $/ \mathrm{Ru}_{2}$ & $\mathrm{CH}_{2} \mathrm{Cl}_{2}$ & +1.606 & 151 & --- & --- \\
$\mathbf{6}$ & $/ \mathrm{Ru}_{2}$ & $\mathrm{MeCN}^{2}$ & $+1.644,+1.888$ & n.d. & 244 & $10^{4.13}$ \\
$\mathbf{7}$ & $/ \mathrm{Ru}_{2}$ & $\mathrm{CH}_{2} \mathrm{Cl}_{2}$ & +1.434 & 122 & --- & --- \\
$\mathbf{7}$ & $/ \mathrm{Ru}_{2}$ & $\mathrm{MeNO}_{2}$ & $+1.283,+1.417$ & 95,95 & 134 & $10^{2.26}$ \\
$\mathbf{8}$ & $/ \mathrm{Ru}$ & $\mathrm{CH}_{2} \mathrm{Cl}_{2}$ & +1.583 & 116 & --- & --- \\
$\mathbf{9}$ & $/ \mathrm{Ru}$ & $\mathrm{MeCN}^{10}$ & +1.619 & 104 & --- & --- \\
$\mathbf{1 0}$ & $/ \mathrm{Ru}$ & $\mathrm{CH}_{2} \mathrm{Cl}_{2}$ & +1.446 & 103 & --- & ---
\end{tabular}


a) $0.1 \mathrm{M}\left[\mathrm{NBu}_{4}\right]\left[\mathrm{PF}_{6}\right]$ as supporting analyte, sweep rate $50 \mathrm{mV} \mathrm{s}^{-1}$, potentials referenced to internal $\mathrm{Fc}^{+} / \mathrm{Fc}\left(E_{1 / 2}\right.$ $=0.41 \mathrm{~V})$, b) $\Delta E_{\mathrm{p}}=E_{\mathrm{pa}}-E_{\mathrm{pc}} ;$ c) $K_{\mathrm{c}}=\exp \left(\Delta E_{1 / 2} / 0.059\right)$.

Complex 6 was measured in $\mathrm{MeCN}$ because its solubility in $\mathrm{CH}_{2} \mathrm{Cl}_{2}$ is low and $\mathrm{NMR}$ experiments showed decomposition in $\mathrm{MeNO}_{2}$. A reversible redox process was observed at $E_{1 / 2}\left(\mathbf{6}^{\mathbf{2}} / \mathbf{6}\right)=+1.574 \mathrm{~V}$, comparable to the monometallic model complex $9\left(E_{1 / 2}\left(\mathbf{9}^{+} / \mathbf{9}\right)=\right.$ $+1.619 \mathrm{~V}$; Fig. 4). No further oxidation occurred up to $+2.1 \mathrm{~V}$. Compound 6 is unstable at potentials higher than $+1.8 \mathrm{~V}$ and decomposed during electrochemical cycles, due presumably to the poor stabilization of the ruthenium(III) center by MeCN ligands. However, DPV measurements in an optically transparent thin-layer electrochemical (OTTLE) cell ${ }^{[30]}$ revealed two separate processes of similar intensity which were attributed to a stepwise oxidation of the two ruthenium(II) centers with $E_{1 / 2}\left(\mathbf{6}^{+} / \mathbf{6}\right)=+1.644 \mathrm{~V}$ and $E_{1 / 2}\left(\mathbf{6}^{2+} / \mathbf{6}^{+}\right)=+1.888 \mathrm{~V}$. These data suggest that a mixed-valence $\mathrm{Ru}^{\mathrm{II}} / \mathrm{Ru}^{\mathrm{III}}$ state is accessible. Based on the $244 \mathrm{mV}$ potential difference between the two oxidation processes and the ensuing comproportionation constant $K_{\mathrm{c}}=10^{4.13},{ }^{[31]}$ complex 6 corresponds to a Class II/III borderline system according to the Robin and Day classification. ${ }^{[29,32]}$ These results demonstrate for the first time that efficient electronic communication of two metal centers through a rigid carbene linker is achievable. This intermetallic coupling confirms that conjugation through the benzobis(carbene) linker is effective, thus corroborating the NMR sensitivity of the central arene protons towards peripheral functionalization ( $c f$ NMR discussion above).

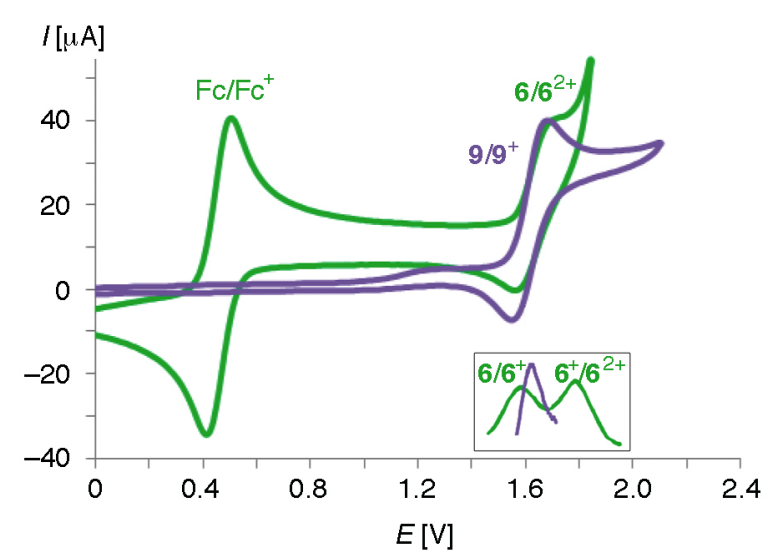

Figure 4. CV plots and relevant DPV sections (inset) of complexes 6 and $9(1 \mathrm{mM}$ in dry MeCN with $0.1 \mathrm{M}$ $\left[\mathrm{NBu}_{4}\right]\left[\mathrm{PF}_{6}\right]$ as supporting electrolyte, $50 \mathrm{mV} \mathrm{s}^{-1}$ scan rate, $\mathrm{Fc}^{+} / \mathrm{Fc}$ used as internal standard with $E_{1 / 2}\left(\mathrm{Fc} / \mathrm{Fc}^{+}\right)=$ $0.41 \mathrm{~V} v s$. SCE).

Qualitatively similar data were recorded for the bpy ligated bimetallic complex 7. CV and DPV measurements in $\mathrm{MeNO}_{2}$ show two distinct redox processes at $E_{1 / 2}\left(\mathbf{7}^{+} / 7\right)=+1.283 \mathrm{~V}$ 
and $E_{1 / 2}\left(7^{2+} / 7^{+}\right)=+1.417 \mathrm{~V}$ (Fig. 5). The lower oxidation potential compared to 6 underlines the stronger donor properties of bpy $v s \mathrm{MeCN} .{ }^{[33]}$ The stability of the oxidized species is much improved and the oxidations are fully reversible. The peak potential separation $\Delta E_{1 / 2}=$ $134 \mathrm{mV}$ is smaller than for the acetonitrile complex $\mathbf{6}$, yielding a comproportionation constant $K_{\mathrm{c}}=10^{2.26}$ (Class II system in the Robin and Day classification). The monometallic analogue 10 undergoes one oxidation with $E_{1 / 2}\left(\mathbf{1 3}^{+} / \mathbf{1 3}\right)=+1.287 \mathrm{~V}$, identical to the first oxidation of $\mathbf{7}$. When measured in $\mathrm{CH}_{2} \mathrm{Cl}_{2}$, complex 7 showed only one single redox process in $\mathrm{CV}$ and DPV $\left(E_{1 / 2}\left(7^{2+} / 7\right)=+1.434 \mathrm{~V}\right)$. The asymmetric shape of the DPV signal and the large anodic peak current hint to fast decomposition in this solvent (Fig. S4).

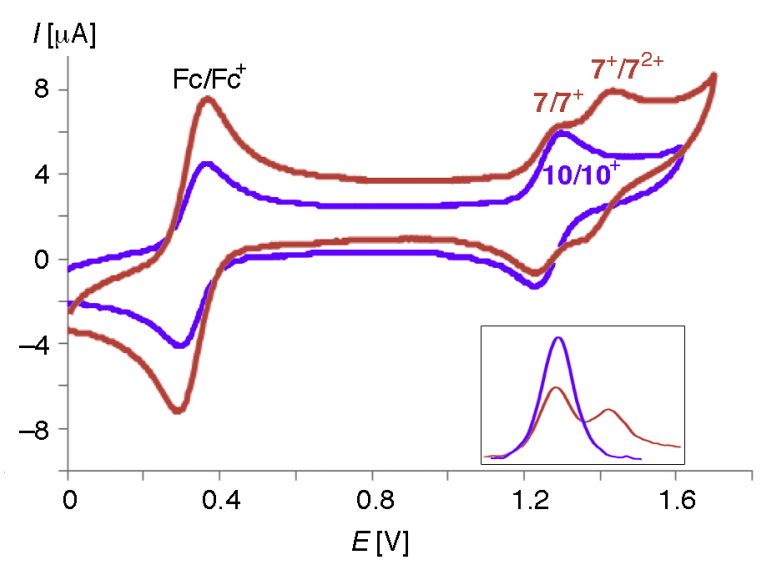

Figure 5. $\mathrm{CV}$ plots and relevant DPV sections (inset) of complexes 7 and $\mathbf{1 0}\left(1 \mathrm{mM}\right.$ in dry $\mathrm{MeNO}_{2}$ with $0.1 \mathrm{M}$ $\left[\mathrm{NBu}_{4}\right]\left[\mathrm{PF}_{6}\right]$ as supporting electrolyte, $50 \mathrm{mV} \mathrm{s}^{-1}$ scan rate, $\mathrm{Fc}^{+} / \mathrm{Fc}$ used as internal standard with $E_{1 / 2}\left(\mathrm{Fc} / \mathrm{Fc}^{+}\right)=$ $0.35 \mathrm{~V} v s$. SCE).

Spectroelectrochemistry and Hush Analysis. The mixed-valent species derived from complexes 6 and 7 were further investigated by spectroelectrochemical methods using an OTTLE cell. ${ }^{[30,34]}$ Complex $\mathbf{6}$ shows a strongly potential-dependent absorption behavior (Fig. 6). In the absence of an applied potential, the complex features a strong absorption band at $333 \mathrm{~nm}$, tentatively assigned to a metal-to-ligand charge transfer band. At $+1.37 \mathrm{~V}$, the spectrum shows a markedly reduced intensity of the UV absorption and a broad absorption in the NIR region $\left(\lambda_{\max }=1593 \mathrm{~nm}, \varepsilon=13,100 \mathrm{M}^{-1} \mathrm{~cm}^{-1}\right)$ that is diagnostic for an intervalence charge transfer (IVCT) and thus supports the formation of a mixed-valent $\mathrm{Ru}^{\mathrm{III}} / \mathrm{Ru}^{\mathrm{II}}$ species $\mathbf{6}^{+}$. Further increase of the potential to $+1.6 \mathrm{~V}$ reduces the IVCT intensity. The fully oxidized $\mathrm{Ru}^{\mathrm{III}} / \mathrm{Ru}^{\mathrm{III}}$ species $\mathbf{6}^{2+}$ is characterized by a shallow absorption maximum at $\lambda_{\max }=838 \mathrm{~nm}$ and a transparent absorption window until nearly $300 \mathrm{~nm}$. Complex 7 features qualitatively identical properties, including a MLCT band at $\lambda_{\max }=411 \mathrm{~nm}$, a broad IVCT band centered 
at $1652 \mathrm{~nm}\left(\varepsilon=2780 \mathrm{M}^{-1} \mathrm{~cm}^{-1}\right)$ upon applying a $+1.23 \mathrm{~V}$ potential, and a weak absorption at $733 \mathrm{~nm}$ for the fully oxidized species $7^{2+}$ at $+1.5 \mathrm{~V}$ (Fig. S5).

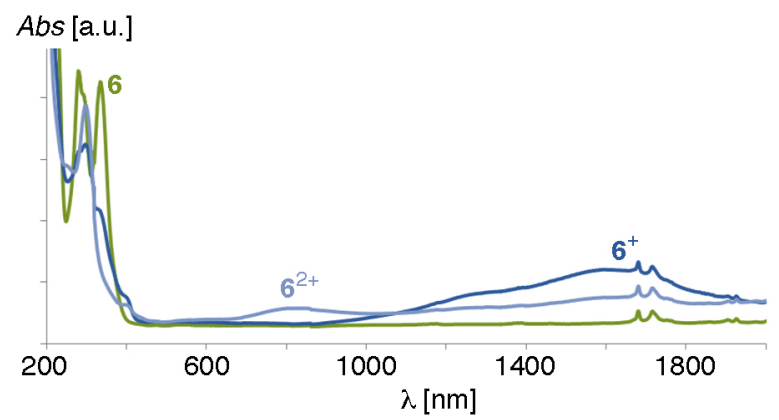

Figure 6. Absorption spectra (MeCN solutions) of complexes $\mathbf{6}$ at $0.0 \mathrm{~V}$ (green), $\mathbf{6}^{+}$at $+1.37 \mathrm{~V}$ (dark blue) and $\mathbf{6}^{2+}$ at $+1.6 \mathrm{~V}$ (light blue).

The stability of the oxidized species was evaluated by time-dependent monitoring of the IVCT absorbance and the band around $800 \mathrm{~nm}$, respectively. Thus exposing complex 6 to a potential of $+1.46 \mathrm{~V}$ for prolonged periods of time induces a gradual decay of the absorbance at $1590 \mathrm{~nm}$ to about $50 \%$ within $1 \mathrm{~h}$ (Fig. S6). At a higher potential $(+1.6 \mathrm{~V})$, the decay is even faster and the absorbance at $820 \mathrm{~nm}$ is depleted within few minutes ( $t_{1 / 2}$ ca. $\left.2 \mathrm{~min}\right)$, suggesting a low stability of $6^{+}$and even a lower one for $\mathbf{6}^{2+}$. Moreover, in a CV measurement of 6 between +1.0 and $+2.0 \mathrm{~V}$, the IVCT absorption intensity in the anodic scan is reduced to about $20 \%$ of the absorption during the cathodic scan (Fig. 7a). These measurements thus corroborate the poor stability of oxidized $\mathbf{6}^{+}$and $\mathbf{6}^{2+}$ as deduced from initial $\mathrm{CV}$ measurements (see above).

a)

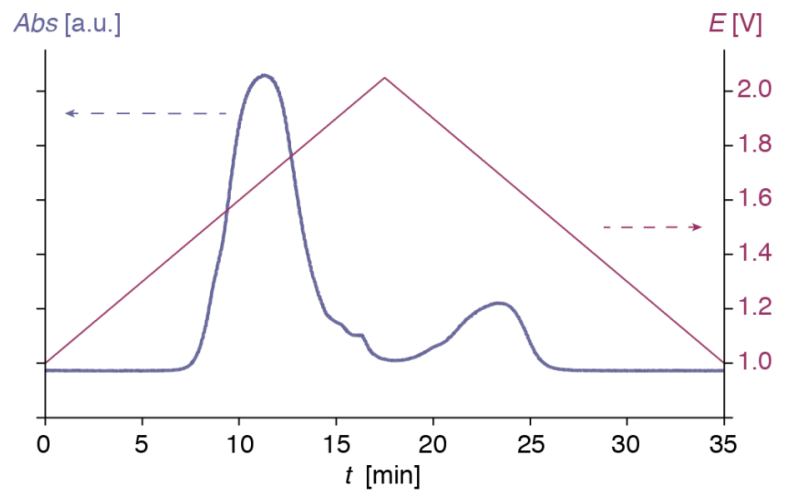

b)

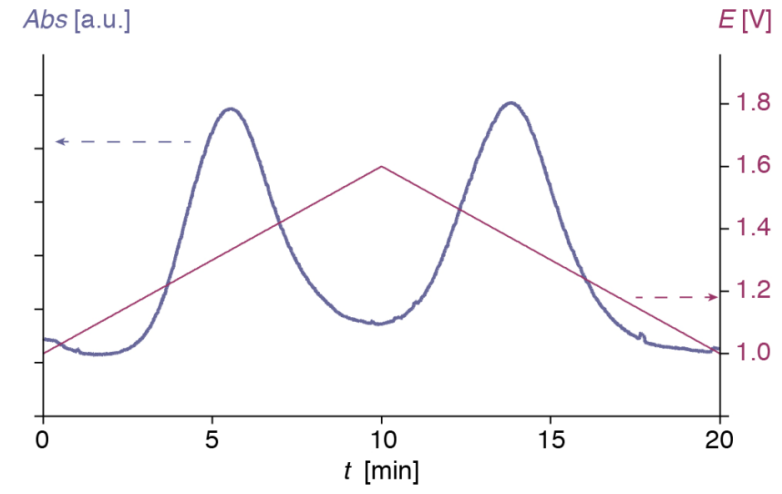

Fig 7. a) Absorbance change at $1590 \mathrm{~nm}$ upon a redox cycle between $1.0-2.0 \mathrm{~V}$ of 6 (1 mM in MeCN, $1 \mathrm{mV} \mathrm{s}^{-1}$ scan rate); b) Absorbance change at $1730 \mathrm{~nm}$ upon a redox cycle between 1.0-1.6 V of 7 (1 $\mathrm{mM}$ in $\mathrm{MeNO}_{2}, 1$ $\mathrm{mV} \mathrm{s}^{-1}$ scan rate).

In contrast, the bpy spectator ligands greatly enhance the stability of the oxidized forms of 7 and hence improve the reversibility substantially. For example, the decay of the IVCT absorbance band of the mixed-valent $\mathrm{Ru}^{\mathrm{II}} / \mathrm{Ru}^{\mathrm{III}}$ species $7^{+}$is only moderate $(\sim 5 \%$ decrease 
within $100 \mathrm{~min}$ ), probably due to disproportionation. The fully oxidized $\mathrm{Ru}^{\mathrm{III}} / \mathrm{Ru}^{\mathrm{III}}$ complex $7^{2+}$ did not show any signs of degradation (Fig. S7). Moreover, the IVCT absorbance of the species at $1730 \mathrm{~nm}$ is equally intense in anodic and cathodic scans (Fig. 7b). These results underline the relevance of a judicious choice of spectator ligands for both stability and electronic coupling. ${ }^{[35]}$

Analysis of the IVCT bands by Marcus' theory ${ }^{[36]}$ and by methods developed by Hush ${ }^{[5 b, d]}$ allows the degree of coupling of the metal centers to be further detailed (Table 4). The IVCT bands for $6^{+}$and $7^{+}$is considerably asymmetric (Fig. S8), with the bandwidth at half height on the high energy side, $\Delta v_{1 / 2}$ (high), about twice as large as that at the low energy side, $\Delta v_{1 / 2}$ (low). The observed bandwidth at half height $\Delta v_{1 / 2}$ (obs) $=2412 \mathrm{~cm}^{-1}$ for $6^{+}$and $2219 \mathrm{~cm}^{-1}$ for $7^{+}$. These values are significantly smaller than the values calculated from the Hush approximation for a valence-trapped class II system $\left(\Delta v_{1 / 2}\right.$ (calcd) $3808 \mathrm{~cm}^{-1}$ and $3736 \mathrm{~cm}^{-1}$ for $\mathbf{6}^{+}$and $7^{+}$, respectively). ${ }^{[5 \mathrm{~d}, 37]}$ These deviations suggest a substantial degree of valence delocalization. The electronic coupling parameter $H_{\mathrm{ab}}$ was calculated to be $729 \mathrm{~cm}^{-1}(0.090 \mathrm{eV})$ and $377 \mathrm{~cm}^{-1}$ $(0.047 \mathrm{eV})$, respectively. ${ }^{[5]}$ The different $H_{\mathrm{ab}}$ values determined for $\mathbf{6}^{+}$and $7^{+}$may potentially hint to a strong solvent dependence, which is characteristic for a class II system. ${ }^{[1 \mathrm{~b}]}$ However, since all further electrochemical and spectroscopic analyses point to borderline class II/III systems, we attribute this difference to a better $\mathrm{d}_{\mathrm{M}}-\pi_{\mathrm{L}}$ overlap in complex 6 containing weakly donating ancillary $\mathrm{MeCN}$ ligands, which strengthen the $\mathrm{M}-\mathrm{CNHC}$ bond and hence increase the electronic coupling of the metal centers. Accordingly, the valence delocalization in $\mathbf{6}^{+}$is more pronounced than in complex $7^{+}$containing two bpy spectator ligands. In agreement with the classification of $6^{+}$and $7^{+}$as borderline valence-trapped/delocalized mixed-valent systems, the delocalization parameter $\Gamma$ is very close to 0.5 .

Table 4. Spectroscopic analysis of mixed-valence complexes $6^{+}$and $7^{+}$a)

\begin{tabular}{ccccccccc}
\hline & Solvent & $v_{\max }$ & $\varepsilon_{\max }$ & $\Delta v_{1 / 2(\mathrm{obs})}$ & $\Delta v_{1 / 2 \text { (calcd) }}$ & asymmetry & $H_{\mathrm{ab}}{ }^{\mathrm{c})}$ & $\Gamma$ \\
\hline $\mathbf{6}^{+}$ & $\mathrm{MeCN}$ & 6277 & 13078 & 2412 & 3808 & 1.87 & $729 \mathrm{~cm}^{-1}(0.0904 \mathrm{eV})$ & 0.37 \\
$\mathbf{7}^{+}$ & $\mathrm{MeNO}_{2}$ & 6042 & 2783 & 2219 & 3736 & 2.06 & $377 \mathrm{~cm}^{-1}(0.0467 \mathrm{eV})$ & 0.41 \\
\hline
\end{tabular}

a) $v$ in $\mathrm{cm}^{-1}, \varepsilon$ in $\mathrm{M}^{-1} \mathrm{~cm}^{-1}$; b) asymmetry of IVCT band determined as ratio $\Delta v_{1 / 2}$ (high) $/ \Delta v_{1 / 2}$ (low); c) Ru...Ru distance $\mathrm{R}=10.537 \AA$ from $\mathrm{X}$-ray crystal structure of $\mathbf{6}$ ).

\section{Conclusions}

By introducing rigidly planar chelating pyridyl wingtip groups, ditopic benzobis(carbene) ligands become effective linkers for imparting electronic coupling between two coordinated 
ruthenium centers. Intermetallic communication is critically triggered by appropriate alignment of the metal $4 \mathrm{~d}$ and the ligand $\pi$ orbitals as a key principle to overcome the hitherto poor coupling in dicarbene species. Small overlap and hence insignificant $\mathrm{Ru}$...Ru coupling results from coordination of the chelate to pseudo-tetrahedral metal coordination geometries as in the cymene complex $\mathbf{5}$, and also emanates from monodentate carbene coordination, since the carbene is typically rotated out of the metal coordination plane by $30-45^{\circ}$. In contrast, chelation to octahedral metal centers as in $\mathbf{6}$ and 7 induces sufficiently large $d_{M}-\pi_{L}$ overlap for imparting a high degree of intermetallic electronic communication, reminiscent of the poor $v s$ pronounced $\pi$ bonding established in pyridine and bipyridine complexes, respectively. These data lend further support to the relevance of $\pi$ contributions to the metal-NHC bond.

Appropriate substitution of the ancillary ligands enhances the efficiency of the electronic communication and thus provides an opportunity for tailoring the electronic properties of the redox switch. Thus, while spectro-electrochemcial analyses indicate that both $\mathrm{MeCN}$ and bpy spectator ligands provide borderline class-II/III systems, valence delocalization is more pronounced in complex 6 with peripheral $\mathrm{MeCN}$ ligands than in complex 7 containing bpy spectator ligands. Besides affecting the stability of the different oxidation states and the reversibility of the redox processes, spectator ligands thus also influence the degree of communication. This relevance needs to be taken into account when designing a next generation of molecular switches based on the bis(carbene) synthon.

Our results provide unambiguous evidence that N-heterocyclic carbene-based ligands are suitable linkers for the fabrication of molecular redox switches. They constitute synthetically versatile alternatives to the more popular oligopyridine- and alkyne-derived linkers, thus offering to novel synthons for application in organometallic polymer chemistry, in molecular electronics, and potentially also in computing.

\section{Experimental Section}

General comments. Starting materials were commercially available and used as received. Solvents were purified using a Thermovac alumina/catalyst column system. The synthesis of complexes $\mathbf{8}$ and $\mathbf{1 0}$ was described previously. ${ }^{[25 \mathrm{e}]}$ Where indicated, reactions were conducted in a Biotage Initiator Microwave Synthesizer. ${ }^{1} \mathrm{H}$ and ${ }^{13} \mathrm{C}\left\{{ }^{1} \mathrm{H}\right\}$ NMR spectra were recorded with Bruker spectrometers at RT unless stated otherwise. Chemical shifts $(\delta)$ are given in ppm relative to signals of residual protio solvent (coupling constants $J$ in $\mathrm{Hz}$ ). Signals were 
assigned with the aid of two-dimensional cross-coupling experiments. Elemental analyses were performed by the Microanalytical Laboratory of the ETH Zürich (Switzerland).

Electrochemistry. Electrochemical studies were carried out using an EG\&G Princeton Applied Research Potentiostat, Model 273A, employing a gas-tight three electrode cell under an argon atmosphere. A glassy carbon disk with $3.41 \mathrm{~mm}^{2}$ surface area was used as the working electrode and was polished before each measurement. The reference electrode was $\mathrm{Ag} / \mathrm{AgCl}$ and the counter electrode was a Pt wire. In all experiments, $\mathrm{Bu}_{4} \mathrm{NPF}_{6}(0.1 \mathrm{M}$ in dry solvent) was used as supporting electrolyte with analyte concentrations of approximately 1 $\mathrm{mM}$. Measurements were performed at different scan rates $\left(50-250 \mathrm{mV} \mathrm{s}^{-1}\right)$. All redox potentials were referenced to the ferrocenium/ferrocene couple $\left(\mathrm{Fc}^{+} / \mathrm{Fc}\right)$ as internal standard with $E_{1 / 2}\left(\mathrm{Fc}^{+} / \mathrm{Fc}\right) v s . \mathrm{SCE}=+0.46 \mathrm{~V}$ in $\mathrm{CH}_{2} \mathrm{Cl}_{2},+0.40 \mathrm{~V}$ in $\mathrm{MeCN},+0.35 \mathrm{~V}$ in $\mathrm{MeNO}_{2}{ }^{[38]}$ Spectroelectrochemical studies were performed using an EG\&G Princeton Applied Research Potentiostat, Model 273A and a Perkin Elmer UV-Vis-NIR Spectrometer, Model Lambda 900 , employing an optically transparent thin-layer electrochemical (OTTLE) cell. ${ }^{[30]}$ In all experiments, $\mathrm{Bu}_{4} \mathrm{NPF}_{6}\left(0.1 \mathrm{M}\right.$ in $\mathrm{MeCN}$ or $\left.\mathrm{MeNO}_{2}\right)$ was used as supporting electrolyte with analyte concentrations of approximately $1 \mathrm{mM}$. For Hush analysis, ${ }^{[5]}$ data were first treated to remove solvent artifacts by subtracting the absorbance at ground potential, assuming that there is no relevant absorbance in the NIR region but background and solvent. The baseline was corrected and absorbance values were smoothened over 9 data points. The IVCT band of $\mathbf{6}^{+}\left(v_{\max }=6277 \mathrm{~cm}^{-1}\right)$ contains a shoulder towards high energy. Assuming that the shoulder arises from a minor decomposition product, it was removed by curve fitting. Transformation from absorbance to molar extinction $\varepsilon$ was calculated via Beer-Lambert law (1 $\mathrm{mM}$ concentrations, path length $d=0.2 \mathrm{~mm}$ for the OTTLE cell). Integrals were calculated numerically and yielded induced dipole moment $\mu_{\mathrm{ge}}=7.31 \mathrm{D}$ for $\mathbf{6}^{+}$and $3.16 \mathrm{D}$ for $7^{+}$ according to Eq. 1

$$
\mu_{\mathrm{ge}}=0.09584\left(\int \varepsilon(v) \partial v / v_{\max }\right)^{1 / 2}
$$

The electronic coupling was calculated according to Eq. 2

$$
H_{\mathrm{ab}}=\mu_{\mathrm{ge}} \times v_{\max } /(\mathrm{e} \times R)
$$

with $R$ taken from the $\mathrm{Ru}$...Ru distance in $\mathbf{6}$ as determined by $\mathrm{X}$-ray crystallography $(10.537$ $\AA$ ) and is the elementary charge. The delocalization parameter $\Gamma$ was calculated according to Eq. 3

$$
\Gamma=1-\left(v_{1 / 2(\mathrm{obs})} / v_{1 / 2(\text { calcd })}\right)
$$


with $v_{1 / 2 \text { (calcd) }}=\left(2310 \times v_{\max }\right)^{1 / 2}$.

Synthesis of 1. 1,5-Dichloro-2,4-dinitrobenzene (2.76 g, $11.6 \mathrm{mmol})$ and 2-aminopyridine $\left(24.0 \mathrm{~g}, 255 \mathrm{mmol}\right.$ ) were stirred neat at $90^{\circ} \mathrm{C}$ for $3 \mathrm{~d}$. The mixture was poured into $\mathrm{MeCN}$ ( 50 $\mathrm{mL}$ ) and water was added until a yellow precipitate formed. This precipitate was isolated by filtration and dried in vacuo to yield $\mathbf{1}$ as an analytically pure yellow solid $(3.59 \mathrm{~g}, 87 \%)$. ${ }^{1} \mathrm{H}$ NMR (360 MHz CDCl $): \delta=10.64$ (br s, $2 \mathrm{H}, \mathrm{NH}), 10.26\left(\mathrm{~s}, 1 \mathrm{H}, \mathrm{H}_{\mathrm{Ar}}\right), 9.38\left(\mathrm{~s}, 1 \mathrm{H}, \mathrm{H}_{\mathrm{Ar}}\right), 8.44$ $\left(\mathrm{d},{ }^{3} J_{\mathrm{HH}}=4.5 \mathrm{~Hz}, 2 \mathrm{H}, \mathrm{H}_{\mathrm{py}}\right), 7.75\left(\mathrm{t},{ }^{3} J_{\mathrm{HH}}=8.0 \mathrm{~Hz}, 2 \mathrm{H}, \mathrm{H}_{\mathrm{py}}\right), 7.17\left(\mathrm{~d},{ }^{3} J_{\mathrm{HH}}=8.0 \mathrm{~Hz}, 2 \mathrm{H}, \mathrm{H}_{\mathrm{py}}\right)$, $7.09\left(\mathrm{dd},{ }^{3} \mathrm{~J}_{\mathrm{HH}}=4.5 \mathrm{~Hz},{ }^{3} \mathrm{~J}_{\mathrm{HH}}=8.0 \mathrm{~Hz}, 2 \mathrm{H}, \mathrm{H}_{\mathrm{py}}\right) \cdot{ }^{13} \mathrm{C}\left\{{ }^{1} \mathrm{H}\right\} \mathrm{NMR}\left(75 \mathrm{MHz}, \mathrm{CDCl}_{3}\right): \delta=152.5$ $\left(\mathrm{C}_{\mathrm{py}}-\mathrm{C}\right), 148.1\left(\mathrm{C}_{\mathrm{py}}-\mathrm{H}\right), 143.4\left(\mathrm{C}_{\mathrm{Ar}}-\mathrm{NO}_{2}\right), 138.2\left(\mathrm{C}_{\mathrm{py}}-\mathrm{H}\right), 127.9\left(\mathrm{C}_{\mathrm{Ar}}-\mathrm{H}\right), 126.6\left(\mathrm{C}_{\mathrm{Ar}}-\mathrm{NH}\right)$, $119.3\left(\mathrm{C}_{\mathrm{py}}-\mathrm{H}\right), 114.9\left(\mathrm{C}_{\mathrm{py}}-\mathrm{H}\right), 103.4\left(\mathrm{C}_{\mathrm{Ar}}-\mathrm{H}\right)$. Elem. Anal. Calcd for $\mathrm{C}_{16} \mathrm{H}_{12} \mathrm{~N}_{6} \mathrm{O}_{4}(352.31): \mathrm{C}$ 54.55, H 3.43, N 23.84\%; Found C 54.71, H 3.52, N 23.88\%.

Synthesis of 2. Compound 1 ( $800 \mathrm{mg}, 2.3 \mathrm{mmol})$ was dissolved in a mixture of $\mathrm{HC}(\mathrm{OEt})_{3}(26$ $\mathrm{mL})$ and $\mathrm{HCOOH}(85 \%, 2.2 \mathrm{~mL}, 58 \mathrm{mmol})$ under argon atmosphere. Sodium formate $(3.56 \mathrm{~g}$, $52 \mathrm{mmol})$ and $\mathrm{Pd} / \mathrm{C} 10 \%(0.6 \mathrm{mg}, 0.52 \mathrm{mmol})$ were added and the reaction was stirred at 100 ${ }^{\circ} \mathrm{C}$ for $36 \mathrm{~h}$. After cooling, the reaction mixture was filtered and the filtrate treated with aqueous $\mathrm{HCl}(6 \%)$ and stirred for $10 \mathrm{~min}$. The yellow solution was treated with aqueous $\mathrm{NaOH}(10 \%)$ until basic and allowed to stand for $1 \mathrm{~h}$. The resulting solid was collected by filtration, washed with $\mathrm{H}_{2} \mathrm{O}$ and dried to yield crude $2(567 \mathrm{mg}, 81 \%)$. Recrystallization from $\mathrm{CH}_{2} \mathrm{Cl}_{2} /$ pentane mixture afforded an analytically pure sample. ${ }^{1} \mathrm{H}$ NMR $\left(300 \mathrm{MHz} \mathrm{CDCl}_{3}\right): \delta$ $=8.92\left(\mathrm{~s}, 1 \mathrm{H}, \mathrm{H}_{\mathrm{Ar}}\right), 8.66\left(\mathrm{dd},{ }^{3} J_{\mathrm{HH}}=4.8 \mathrm{~Hz},{ }^{4} J_{\mathrm{HH}}=1.5 \mathrm{~Hz}, 2 \mathrm{H}, \mathrm{H}_{\mathrm{py}}\right), 8.62(\mathrm{~s}, 2 \mathrm{H}, \mathrm{NCHN})$, $8.32\left(\mathrm{~s}, 1 \mathrm{H}, \mathrm{H}_{\mathrm{Ar}}\right), 7.95\left(\mathrm{td},{ }^{3} J_{\mathrm{HH}}=8.1 \mathrm{~Hz},{ }^{4} J_{\mathrm{HH}}=1.5 \mathrm{~Hz}, 2 \mathrm{H}, \mathrm{H}_{\mathrm{py}}\right), 7.65\left(\mathrm{~d},{ }^{3} J_{\mathrm{HH}}=8.1 \mathrm{~Hz}, 2 \mathrm{H}\right.$, $\left.\mathrm{H}_{\mathrm{py}}\right), 7.33\left(\mathrm{dd},{ }^{3} \mathrm{~J}_{\mathrm{HH}}=8.1 \mathrm{~Hz},{ }^{3} J_{\mathrm{HH}}=4.9 \mathrm{~Hz}, 2 \mathrm{H}, \mathrm{H}_{\mathrm{py}}\right) \cdot{ }^{13} \mathrm{C}\left\{{ }^{1} \mathrm{H}\right\} \mathrm{NMR}\left(75 \mathrm{MHz}, \mathrm{CDCl}_{3}\right): \delta=$ $150.3\left(\mathrm{C}_{\mathrm{py}}-\mathrm{C}\right), 149.5\left(\mathrm{C}_{\mathrm{py}}-\mathrm{H}\right), 142.2(\mathrm{NCHN}), 142.2\left(C_{\mathrm{Ar}}-\mathrm{N}\right), 139.0\left(\mathrm{C}_{\mathrm{py}}-\mathrm{H}\right), 130.6\left(\mathrm{C}_{\mathrm{Ar}}-\mathrm{N}\right)$, 121.6 $\left(\mathrm{C}_{\mathrm{py}}-\mathrm{H}\right), 114.2\left(\mathrm{C}_{\mathrm{py}}-\mathrm{H}\right), 111.0\left(\mathrm{C}_{\mathrm{Ar}}-\mathrm{H}\right), 96.2\left(\mathrm{C}_{\mathrm{Ar}}-\mathrm{H}\right)$. Elem. Anal. Calcd for $\mathrm{C}_{18} \mathrm{H}_{12} \mathrm{~N}_{6}$ (312.33) $\times 1 / 8 \mathrm{CH}_{2} \mathrm{Cl}_{2}: \mathrm{C} 67.41, \mathrm{H} 3.82$, N 26.02\%; Found: C 67.78, H 4.10, N 25.61\%.

Synthesis of 3. Compound $2(567 \mathrm{mg}, 1.8 \mathrm{mmol})$ was suspended in a mixture of MeI (2.0 $\mathrm{mL}, 32 \mathrm{mmol})$ and $\mathrm{MeCN}(0.1 \mathrm{~mL})$. The reaction mixture was sealed in a pressure tube and heated to $110{ }^{\circ} \mathrm{C}$ for $48 \mathrm{~h}$. After cooling the reaction mixture was filtered and the residue was washed with a minimum amount of $\mathrm{MeCN}$ and $\mathrm{Et}_{2} \mathrm{O}$ and dried in vacuo, yielding 3 as analytically pure and slightly hygroscopic off-white powder (569 mg, 52\%). ${ }^{1} \mathrm{H}$ NMR (400 
MHz, DMSO- $\left.\mathrm{d}_{6}\right): \delta=10.84(\mathrm{~s}, 2 \mathrm{H}, \mathrm{NCHN}), 9.65\left(\mathrm{~s}, 1 \mathrm{H}, \mathrm{H}_{\mathrm{Ar}}\right), 9.13\left(\mathrm{~s}, 1 \mathrm{H}, \mathrm{H}_{\mathrm{Ar}}\right), 8.85\left(\mathrm{~d},{ }^{3} J_{\mathrm{HH}}\right.$ $\left.=4.5 \mathrm{~Hz}, 2 \mathrm{H}, \mathrm{H}_{\mathrm{py}}\right), 8.36\left(\mathrm{t},{ }^{3} J_{\mathrm{HH}}=8.0 \mathrm{~Hz}, 2 \mathrm{H}, \mathrm{H}_{\mathrm{py}}\right), 7.65\left(\mathrm{~d},{ }^{3} J_{\mathrm{HH}}=8.0 \mathrm{~Hz}, 2 \mathrm{H}, \mathrm{H}_{\mathrm{py}}\right), 7.33(\mathrm{dd}$, $\left.2 \mathrm{H},{ }^{3} \mathrm{~J}_{\mathrm{HH}}=8.0 \mathrm{~Hz},{ }^{3} \mathrm{~J}_{\mathrm{HH}}=4.5 \mathrm{~Hz}, 2 \mathrm{H}, \mathrm{H}_{\mathrm{py}}\right), 4.33\left(\mathrm{~s}, 6 \mathrm{H}, \mathrm{N}-\mathrm{CH}_{3}\right) .{ }^{13} \mathrm{C}\left\{{ }^{1} \mathrm{H}\right\} \mathrm{NMR}(100 \mathrm{MHz}$, DMSO- $\left.\mathrm{d}_{6}\right): \delta=149.4\left(\mathrm{C}_{\mathrm{py}}-\mathrm{C}\right), 147.5\left(\mathrm{C}_{\mathrm{py}}-\mathrm{H}\right), 146.6(\mathrm{NCHN}), 140.8\left(\mathrm{C}_{\mathrm{py}}-\mathrm{H}\right), 131.4\left(\mathrm{C}_{\mathrm{Ar}}-\mathrm{N}\right)$, $128.5\left(\mathrm{C}_{\mathrm{Ar}}-\mathrm{N}\right), 125.2\left(\mathrm{C}_{\mathrm{py}}-\mathrm{H}\right), 116.8\left(\mathrm{C}_{\mathrm{py}}-\mathrm{H}\right), 103.6\left(\mathrm{C}_{\mathrm{Ar}}-\mathrm{H}\right), 99.7\left(\mathrm{C}_{\mathrm{Ar}}-\mathrm{H}\right), 34.5\left(\mathrm{~N}-\mathrm{CH}_{3}\right)$. Elem. Anal. Calcd for $\mathrm{C}_{20} \mathrm{H}_{18} \mathrm{I}_{2} \mathrm{~N}_{6}(596.21) \times 1 / 2 \mathrm{H}_{2} \mathrm{O}$ : C 39.69, H 3.16, N 13.89\%; Found: C $39.57, \mathrm{H} 3.26, \mathrm{~N} 13.82 \%$.

Synthesis of 4. Compound $3(569 \mathrm{mg}, 1.0 \mathrm{mmol})$ was dissolved in $\mathrm{H}_{2} \mathrm{O}(80 \mathrm{~mL})$ and a solution of $\left(\mathrm{NH}_{4}\right) \mathrm{PF}_{6}(3.23 \mathrm{~g}, 20 \mathrm{mmol})$ in $\mathrm{H}_{2} \mathrm{O}(10 \mathrm{~mL})$ was added under vigorous stirring. The formed precipitate was collected by filtration and dried in vacuo to yield $\mathbf{4}$ as analytically pure white powder $(502 \mathrm{mg}, 87 \%) .{ }^{1} \mathrm{H}$ NMR (360 MHz, DMSO- $\left.\mathrm{d}_{6}\right): \delta=10.80(\mathrm{~s}, 2 \mathrm{H}$, $\mathrm{NCHN}), 9.65\left(\mathrm{~s}, 1 \mathrm{H}, \mathrm{H}_{\mathrm{Ar}}\right), 9.08\left(\mathrm{~s}, 1 \mathrm{H}, \mathrm{H}_{\mathrm{Ar}}\right), 8.85\left(\mathrm{~d},{ }^{3} J_{\mathrm{HH}}=4.1 \mathrm{~Hz}, 2 \mathrm{H}, \mathrm{H}_{\mathrm{py}}\right), 8.35\left(\mathrm{t},{ }^{3} J_{\mathrm{HH}}=\right.$ $\left.8.0 \mathrm{~Hz}, 2 \mathrm{H}, \mathrm{H}_{\mathrm{py}}\right), 8.10\left(\mathrm{~d},{ }^{3} J_{\mathrm{HH}}=8.0 \mathrm{~Hz}, 2 \mathrm{H}, \mathrm{H}_{\mathrm{py}}\right), 7.77\left(\mathrm{dd},{ }^{3} J_{\mathrm{HH}}=8.0 \mathrm{~Hz},{ }^{3} J_{\mathrm{HH}}=4.1 \mathrm{~Hz}, 2 \mathrm{H}\right.$, $\left.\mathrm{H}_{\mathrm{py}}\right), 4.32\left(\mathrm{~s}, 6 \mathrm{H}, \mathrm{N}-\mathrm{CH}_{3}\right) .{ }^{13} \mathrm{C}\left\{{ }^{1} \mathrm{H}\right\} \mathrm{NMR}\left(90 \mathrm{MHz}, \mathrm{DMSO}-\mathrm{d}_{6}\right): \delta=149.7\left(\mathrm{C}_{\mathrm{py}}-\mathrm{C}\right), 147.6$ $\left(\mathrm{C}_{\mathrm{py}}-\mathrm{H}\right), 146.7(\mathrm{NCHN}), 140.9\left(\mathrm{C}_{\mathrm{py}}-\mathrm{H}\right), 131.5\left(\mathrm{C}_{\mathrm{Ar}}-\mathrm{N}\right), 128.6\left(\mathrm{C}_{\mathrm{Ar}}-\mathrm{N}\right), 125.4\left(\mathrm{C}_{\mathrm{py}}-\mathrm{H}\right), 116.8$ $\left(\mathrm{C}_{\mathrm{py}}-\mathrm{H}\right), 103.5\left(\mathrm{C}_{\mathrm{Ar}}-\mathrm{H}\right), 99.7\left(\mathrm{C}_{\mathrm{Ar}}-\mathrm{H}\right), 34.5\left(\mathrm{~N}-\mathrm{CH}_{3}\right)$. Elem. Anal. Calcd for $\mathrm{C}_{20} \mathrm{H}_{18} \mathrm{~F}_{12} \mathrm{~N}_{6} \mathrm{P}_{2}$ (632.33): C 37.99, H 2.87, N 13.29\%; Found C 38.12, H 3.06, N 13.24\%.

Synthesis of complex 5. To a suspension of benzobisimidazolium salt 4 (100 mg, $0.16 \mathrm{mmol}$ ) in $\mathrm{MeOH}(10 \mathrm{~mL})$ was added $\mathrm{Ag}_{2} \mathrm{O}(81 \mathrm{mg}, 0.35 \mathrm{mmol})$. The reaction mixture was stirred in the dark under argon at RT for $24 \mathrm{~h}$. All volatiles were evaporated and the residue was suspended in dry $\mathrm{CH}_{2} \mathrm{Cl}_{2}(10 \mathrm{~mL})$. After addition of $\left[\mathrm{RuCl}_{2}(\mathrm{p} \text {-cymene })\right]_{2}(106.4 \mathrm{mg}, 0.17$ $\mathrm{mmol}$ ), the suspension was stirred at RT for $72 \mathrm{~h}$ protected from light. The mixture was then centrifuged and the supernatant was decanted and filtered through a short pad of $\mathrm{Al}_{2} \mathrm{O}_{3}$. After evaporation and drying in vacuo, complex 5 was obtained as an orange solid in a 1:1 mixture of diastereomers (167 mg, 90\%). ${ }^{1} \mathrm{H} \mathrm{NMR}\left(400 \mathrm{MHz}_{\mathrm{CDCl}}\right)$, isomer $A: \delta=9.27\left(\mathrm{~d},{ }^{3} J_{\mathrm{HH}}=\right.$ $\left.5.2 \mathrm{~Hz}, 2 \mathrm{H}, \mathrm{H}_{\mathrm{py}}\right), 7.90-7.96\left(\mathrm{~m}, 4 \mathrm{H}, \mathrm{H}_{\mathrm{py}}\right), 7.84\left(\mathrm{~s}, 1 \mathrm{H}, \mathrm{H}_{\mathrm{Ar}}\right), 7.69\left(\mathrm{~s}, 1 \mathrm{H}, \mathrm{H}_{\mathrm{Ar}}\right), 7.49-7.56(\mathrm{~m}$, $\left.2 \mathrm{H}, \mathrm{H}_{\mathrm{py}}\right), 6.37\left(\mathrm{~d},{ }^{3} J_{\mathrm{HH}}=6.3 \mathrm{~Hz}, 2 \mathrm{H}, \mathrm{H}_{\mathrm{cym}}\right), 6.23\left(\mathrm{~d},{ }^{3} J_{\mathrm{HH}}=6.3 \mathrm{~Hz}, 2 \mathrm{H}, \mathrm{H}_{\mathrm{cym}}\right), 6.14\left(\mathrm{~d},{ }^{3} J_{\mathrm{HH}}=\right.$ $\left.6.5 \mathrm{~Hz}, 2 \mathrm{H}, \mathrm{H}_{\mathrm{cym}}\right), 5.78\left(\mathrm{~d},{ }^{3} J_{\mathrm{HH}}=6.5 \mathrm{~Hz}, 2 \mathrm{H}, \mathrm{H}_{\mathrm{cym}}\right), 3.98\left(\mathrm{~s}, 6 \mathrm{H}, \mathrm{N}-\mathrm{CH}_{3}\right), 2.38\left(\right.$ septet, ${ }^{3} J_{\mathrm{HH}}=$ $\left.6.6 \mathrm{~Hz}, 2 \mathrm{H}, \mathrm{CHMe}_{2}\right), 2.28\left(\mathrm{~s}, 6 \mathrm{H}, \mathrm{cym}-\mathrm{CH}_{3}\right), 0.92\left(\mathrm{~d},{ }^{3} \mathrm{~J}_{\mathrm{HH}}=6.6 \mathrm{~Hz}, 6 \mathrm{H}, \mathrm{CH}-\mathrm{CH}_{3}\right), 0.83(\mathrm{~d}$, $\left.{ }^{3} J_{\mathrm{HH}}=6.6 \mathrm{~Hz}, 6 \mathrm{H}, \mathrm{CH}-\mathrm{CH}_{3}\right)$. Isomer $B: \delta=9.30\left(\mathrm{~d},{ }^{3} J_{\mathrm{HH}}=5.6 \mathrm{~Hz}, 2 \mathrm{H}, \mathrm{H}_{\mathrm{py}}\right), 8.56(\mathrm{~s}, 1 \mathrm{H}$, $\left.\mathrm{H}_{\mathrm{Ar}}\right), 8.45\left(\mathrm{~d},{ }^{3} J_{\mathrm{HH}}=8.3 \mathrm{~Hz}, 2 \mathrm{H}, \mathrm{H}_{\mathrm{py}}\right), 8.33\left(\mathrm{t},{ }^{3} J_{\mathrm{HH}}=8.0 \mathrm{~Hz}, 2 \mathrm{H}, \mathrm{H}_{\mathrm{py}}\right), 8.20\left(\mathrm{~s}, 1 \mathrm{H}, \mathrm{H}_{\mathrm{Ar}}\right), 7.56$ 
$\left(\mathrm{t},{ }^{3} J_{\mathrm{HH}}=6.3 \mathrm{~Hz}, 2 \mathrm{H}, \mathrm{H}_{\mathrm{py}}\right), 6.31\left(\mathrm{~d},{ }^{3} J_{\mathrm{HH}}=6.3 \mathrm{~Hz}, 2 \mathrm{H}, \mathrm{H}_{\mathrm{cym}}\right), 6.28\left(\mathrm{~d},{ }^{3} J_{\mathrm{HH}}=6.3 \mathrm{~Hz}, 2 \mathrm{H}\right.$, $\left.\mathrm{H}_{\mathrm{cym}}\right), 6.05\left(\mathrm{~d},{ }^{3} J_{\mathrm{HH}}=6.5 \mathrm{~Hz}, 2 \mathrm{H}, \mathrm{H}_{\mathrm{cym}}\right), 5.72\left(\mathrm{~d},{ }^{3} J_{\mathrm{HH}}=6.5 \mathrm{~Hz}, 2 \mathrm{H}, \mathrm{H}_{\mathrm{cym}}\right), 4.43(\mathrm{~s}, 6 \mathrm{H}, \mathrm{N}-$ $\left.\mathrm{CH}_{3}\right), 2.46$ (septet, $\left.{ }^{3} \mathrm{~J}_{\mathrm{HH}}=6.6 \mathrm{~Hz}, 2 \mathrm{H}, \mathrm{CHMe}_{2}\right), 2.22\left(\mathrm{~s}, 6 \mathrm{H}, \mathrm{cym}-\mathrm{CH}_{3}\right), 0.92\left(\mathrm{~d},{ }^{3} \mathrm{~J}_{\mathrm{HH}}=6.6\right.$ $\left.\mathrm{Hz}, 6 \mathrm{H}, \mathrm{CH}-\mathrm{CH}_{3}\right), 0.83\left(\mathrm{~d},{ }^{3} \mathrm{~J}_{\mathrm{HH}}=6.6 \mathrm{~Hz}, 6 \mathrm{H}, \mathrm{CH}-\mathrm{CH}_{3}\right) .{ }^{13} \mathrm{C}\left\{{ }^{1} \mathrm{H}\right\} \mathrm{NMR}\left(100 \mathrm{MHz} \mathrm{CDCl}_{3}\right)$, isomer A: $202.8(\mathrm{C}-\mathrm{Ru}), 154.4\left(C_{\mathrm{py}}-\mathrm{C}\right), 153.0\left(\mathrm{C}_{\mathrm{py}}-\mathrm{H}\right), 143.4\left(\mathrm{C}_{\mathrm{py}}-\mathrm{H}\right), 135.7\left(\mathrm{C}_{\mathrm{Ar}}-\mathrm{N}\right), 127.8$ $\left(\mathrm{C}_{\mathrm{Ar}}-\mathrm{N}\right), 125.0\left(\mathrm{C}_{\mathrm{py}}-\mathrm{H}\right), 115.1\left(\mathrm{C}_{\mathrm{py}}-\mathrm{H}\right), 111.7\left(C_{\mathrm{cym}}-\mathrm{C}\right), 108.4\left(C_{\mathrm{cym}}-\mathrm{C}\right), 96.7\left(\mathrm{C}_{\mathrm{Ar}}-\mathrm{H}\right), 95.9$ $\left(\mathrm{C}_{\mathrm{Ar}}-\mathrm{H}\right), 94.3\left(\mathrm{C}_{\mathrm{cym}}-\mathrm{H}\right), 92.9\left(\mathrm{C}_{\mathrm{cym}}-\mathrm{H}\right), 89.5\left(\mathrm{C}_{\mathrm{cym}}-\mathrm{H}\right), 85.2\left(\mathrm{C}_{\mathrm{cym}}-\mathrm{H}\right), 37.4\left(\mathrm{~N}-\mathrm{CH}_{3}\right), 32.1$ $\left(\mathrm{CHMe}_{2}\right), 22.7\left(\mathrm{CH}-\mathrm{CH}_{3}\right), 22.5\left(\mathrm{C}-\mathrm{CH}_{3}\right), 19.6\left(\right.$ cym- $\left.\mathrm{CH}_{3}\right)$. Isomer $B: \delta=203.3(\mathrm{C}-$ $\mathrm{Ru}), 157.4\left(C_{\mathrm{py}}-\mathrm{C}\right), 153.0\left(\mathrm{C}_{\mathrm{py}}-\mathrm{H}\right), 142.9\left(\mathrm{C}_{\mathrm{py}}-\mathrm{H}\right), 134.5\left(\mathrm{C}_{\mathrm{Ar}}-\mathrm{N}\right), 128.8\left(\mathrm{C}_{\mathrm{Ar}}-\mathrm{N}\right), 124.3\left(\mathrm{C}_{\mathrm{py}}-\right.$ $\mathrm{H}), 114.9\left(\mathrm{C}_{\mathrm{py}}-\mathrm{H}\right), 111.2\left(C_{\mathrm{cym}}-\mathrm{C}\right), 108.4\left(C_{\mathrm{cym}}-\mathrm{C}\right), 97.8\left(\mathrm{C}_{\mathrm{Ar}}-\mathrm{H}\right), 95.9\left(\mathrm{C}_{\mathrm{Ar}}-\mathrm{H}\right), 94.3\left(\mathrm{C}_{\mathrm{cym}}-\right.$ $\mathrm{H}), 94.0\left(\mathrm{C}_{\text {cym }}-\mathrm{H}\right), 89.3\left(\mathrm{C}_{\text {cym }}-\mathrm{H}\right), 85.4\left(\mathrm{C}_{\text {cym }}-\mathrm{H}\right), 37.5\left(\mathrm{~N}-\mathrm{CH}_{3}\right), 32.1\left(\mathrm{CHMe}_{2}\right), 22.6(\mathrm{C}-$ $\left.\mathrm{CH}_{3}\right), 22.5\left(\mathrm{C}-\mathrm{CH}_{3}\right), 19.4\left(\mathrm{cym}-\mathrm{CH}_{3}\right)$. Elem. Anal. Calcd for $\mathrm{C}_{40} \mathrm{H}_{42} \mathrm{Cl}_{2} \mathrm{~F}_{12} \mathrm{~N}_{6} \mathrm{P}_{2} \mathrm{Ru}_{2}(1171.79)$ $\times \mathrm{CH}_{2} \mathrm{Cl}_{2}$ : C 39.18, H 3.69, N 6.69\%; Found C 38.98, H 3.90, N 6.97\%.

Synthesis of complex 6. Complex 5 (140 mg, $0.12 \mathrm{mmol})$ was dissolved in $\mathrm{MeCN}(10 \mathrm{~mL})$ and $\mathrm{AgPF}_{6}(121 \mathrm{mg}, 0.48 \mathrm{mmol})$ was added. The mixture was heated to reflux and stirred for $20 \mathrm{~h}$. After cooling, the reaction mixture was poured into $\mathrm{H}_{2} \mathrm{O}(10 \mathrm{~mL})$. The formed precipitate was filtered, washed with $\mathrm{Et}_{2} \mathrm{O}(3 \times 5 \mathrm{~mL})$ and dried to yield analytically pure complex 6 as an off-white powder (91 g, 52\%). X-ray quality crystals were grown by slow diffusion of $\mathrm{Et}_{2} \mathrm{O}$ into a $\mathrm{MeCN}$ solution of 6 at $-20{ }^{\circ} \mathrm{C} .{ }^{1} \mathrm{H} \mathrm{NMR}\left(400 \mathrm{MHz}, \mathrm{CDCl}_{3}\right): \delta=9.05$ $\left(\mathrm{d},{ }^{3} J_{\mathrm{HH}}=5.7 \mathrm{~Hz}, 2 \mathrm{H}, \mathrm{H}_{\mathrm{py}}\right), 8.58\left(\mathrm{~s}, 1 \mathrm{H}, \mathrm{H}_{\mathrm{Ar}}\right), 8.48\left(\mathrm{~d},{ }^{3} J_{\mathrm{HH}}=8.2 \mathrm{~Hz}, 2 \mathrm{H}, \mathrm{H}_{\mathrm{py}}\right), 8.33\left(\mathrm{t},{ }^{3} J_{\mathrm{HH}}=\right.$ $\left.8.2 \mathrm{~Hz}, 2 \mathrm{H}, \mathrm{H}_{\mathrm{py}}\right), 8.11\left(\mathrm{~s}, 1 \mathrm{H}, \mathrm{H}_{\mathrm{Ar}}\right), 7.56\left(\mathrm{dd},{ }^{3} J_{\mathrm{HH}}=8.2 \mathrm{~Hz},{ }^{3} J_{\mathrm{HH}}=5.7 \mathrm{~Hz}, 2 \mathrm{H}, \mathrm{H}_{\mathrm{py}}\right), 4.41(\mathrm{~s}$, $\left.6 \mathrm{H}, \mathrm{N}-\mathrm{CH}_{3}\right), 2.60\left(\mathrm{~s}, 6 \mathrm{H}, \mathrm{NCCH}_{3}\right), 2.09\left(\mathrm{~s}, 12 \mathrm{H}, \mathrm{NCCH}_{3}\right), 1.96\left(\mathrm{~s}, 6 \mathrm{H}, \mathrm{NCCH}_{3}\right) .{ }^{13} \mathrm{C}\left\{{ }^{1} \mathrm{H}\right\}$ NMR (100 MHz, $\left.\mathrm{CDCl}_{3}\right): \delta=207.6(\mathrm{C}-\mathrm{Ru}), 156.4\left(C_{\mathrm{py}}-\mathrm{C}\right), 154.7\left(\mathrm{C}_{\mathrm{py}}-\mathrm{H}\right), 142.2\left(\mathrm{C}_{\mathrm{py}}-\mathrm{H}\right)$, $136.0\left(\mathrm{C}_{\mathrm{Ar}}-\mathrm{N}\right), 129.9\left(\mathrm{C}_{\mathrm{Ar}}-\mathrm{N}\right), 127.9(\mathrm{NCMe}), 126.2(\mathrm{NCMe}), 125.4(\mathrm{NCMe}), 123.4\left(\mathrm{C}_{\mathrm{py}}-\mathrm{H}\right)$, $114.3\left(\mathrm{C}_{\mathrm{py}}-\mathrm{H}\right), 95.9\left(\mathrm{C}_{\mathrm{Ar}}-\mathrm{H}\right), 94.8\left(\mathrm{C}_{\mathrm{Ar}}-\mathrm{H}\right), 37.9\left(\mathrm{~N}-\mathrm{CH}_{3}\right), 4.9\left(\mathrm{NC}-\mathrm{CH}_{3}\right), 4.4\left(\mathrm{NC}-\mathrm{CH}_{3}\right), 1.1$ (NC-CH ). Elem. Anal. Calcd for $\mathrm{C}_{36} \mathrm{H}_{40} \mathrm{~F}_{24} \mathrm{~N}_{14} \mathrm{P}_{4} \mathrm{Ru}_{2}$ (1452.02): C 29.80, H 2.78, N 13.52\%; Found C 29.67, H 2.89, N 13.30\%.

Synthesis of complex 7. A pressure tube was charged with complex 6 (60 mg, $41 \mu \mathrm{mol}), 2,2-$ bipyridine $(60 \mathrm{mg}, 0.38 \mathrm{mmol})$ and $\mathrm{MeNO}_{2}(4 \mathrm{~mL})$ and stirred at $110{ }^{\circ} \mathrm{C}$ for $20 \mathrm{~h}$. After cooling, the orange reaction mixture was poured into $\mathrm{Et}_{2} \mathrm{O}(20 \mathrm{~mL})$ and the formed precipitate was filtered off, washed with $\mathrm{Et}_{2} \mathrm{O}$ and dried to give complex 7 as an orange solid $(86 \mathrm{mg}$, 
95\%). Recrystallization from $\mathrm{CH}_{2} \mathrm{Cl}_{2} /$ pentane gave an analytically pure sample and crystals suitable for an X-ray diffraction analysis. NMR spectroscopy revealed a 1:1 mixture of two diastereomers. ${ }^{1} \mathrm{H}$ NMR (500 MHz, $\left.\mathrm{CDCl}_{3}\right): \delta=8.92\left(\mathrm{~s}, 2 \mathrm{H}, \mathrm{H}_{\mathrm{Ar}}\right), 8.64\left(\mathrm{~d}, 4 \mathrm{H}, \mathrm{H}_{\mathrm{bpy}}\right), 8.63$ (d, $\left.4 \mathrm{H}, \mathrm{H}_{\text {bpy }}\right), 8.62$ (d, 2H, $\left.\mathrm{H}_{\mathrm{py}}\right), 8.61$ (d, 2H, $\left.\mathrm{H}_{\mathrm{bpy}}\right), 8.59$ (d, 2H, $\left.\mathrm{H}_{\mathrm{py}}{ }^{\prime}\right), 8.56$ (d, 2H, $\left.\mathrm{H}_{\text {bpy }}\right), 8.55$ (d, $\left.2 \mathrm{H}, \mathrm{H}_{\mathrm{bpy}}\right), 8.53\left(\mathrm{~d}, 2 \mathrm{H}, \mathrm{H}_{\mathrm{bpy}}\right), 8.26$ (t, 4H, $\left.\mathrm{H}_{\text {bpy }}\right), 8.24$ (d, 2H, $\left.\mathrm{H}_{\mathrm{py}}\right), 8.21$ (t, 4H, $\left.\mathrm{H}_{\text {bpy }}\right), 8.20$ (d, $\left.2 \mathrm{H}, \mathrm{H}_{\text {py }}{ }^{\prime}\right), 8.15$ (t, 2H, $\mathrm{H}_{\text {bpy }}$ ), 8.12 (t, 2H, $\mathrm{H}_{\text {bpy }}$ ), 8.10 (t, 2H, $\mathrm{H}_{\text {bpy }}$ ), 8.09 (t, 2H, $\mathrm{H}_{\text {bpy }}$ ), 8.09 (t, $\left.2 \mathrm{H}, \mathrm{H}_{\mathrm{py}}\right), 8.06$ (t, 2H, $\left.\mathrm{H}_{\text {py }}{ }^{\prime}\right), 8.00$ (d, 2H, $\left.\mathrm{H}_{\text {bpy }}\right), 7.98$ (d, 2H, $\left.\mathrm{H}_{\text {bpy }}\right), 7.86\left(\mathrm{t}, 4 \mathrm{H}, \mathrm{H}_{\text {bpy }}\right), 7.85$ (d, 2H, $\left.\mathrm{H}_{\text {bpy }}\right), 7.80$ (t, 4H, $\mathrm{H}_{\text {bpy }}$ ), 7.79, (d, 2H, $\left.\mathrm{H}_{\text {bpy }}\right), 7.69$ (s, 2H, $\left.\mathrm{H}_{\mathrm{Ar}}\right), 7.58$ (dd, 4H, $\left.\mathrm{H}_{\text {bpy }}\right), 7.45$ (dd, 2H, $\mathrm{H}_{\text {bpy }}$ ), 7.44 (dd, 2H, $\mathrm{H}_{\text {bpy }}$ ), 7.42 (dd, 2H, $\mathrm{H}_{\text {bpy }}$ ), 7.41 (dd, 2H, $\mathrm{H}_{\text {bpy }}$ ), 7.40 (dd, 2H, $\left.\mathrm{H}_{\mathrm{py}}\right), 7.31\left(\mathrm{dd}, 4 \mathrm{H}, \mathrm{H}_{\mathrm{bpy}}\right), 7.30\left(\mathrm{dd}, 2 \mathrm{H}, \mathrm{H}_{\mathrm{py}}{ }^{\prime}\right), 3.50$ (s, $\left.12 \mathrm{H}, \mathrm{N}-\mathrm{CH}_{3}\right) .{ }^{13} \mathrm{C}\left\{{ }^{1} \mathrm{H}\right\} \mathrm{NMR}(125$ $\left.\mathrm{MHz}, \mathrm{CDCl}_{3}\right): \delta=211.1(\mathrm{C}-\mathrm{Ru}), 158.3-156.2\left(\mathrm{C}_{\mathrm{py}}^{2}\right), 156.7-150.3\left(\mathrm{C}_{\mathrm{py}}^{3}\right), 141.5-139.2\left(\mathrm{C}_{\mathrm{py}}^{4}\right)$, 136.7 $\left(\mathrm{C}_{\mathrm{Ar}}-\mathrm{N}\right), 130.3\left(\mathrm{C}_{\mathrm{Ar}}-\mathrm{N}\right), 130.3-124.1\left(\mathrm{C}_{\mathrm{py}}^{5}\right), 125.9-114.4\left(\mathrm{C}_{\mathrm{py}}^{6}\right), 96.2\left(\mathrm{C}_{\mathrm{Ar}}-\mathrm{H}\right), 93.7$ $\left(\mathrm{C}_{\mathrm{Ar}}-\mathrm{H}\right), 34.0\left(\mathrm{~N}-\mathrm{CH}_{3}\right)$. Elem. Anal. Calcd for $\mathrm{C}_{60} \mathrm{H}_{48} \mathrm{~F}_{24} \mathrm{~N}_{14} \mathrm{P}_{4} \mathrm{Ru}_{2}$ (1747.11): $\mathrm{C}$ 41.25, $\mathrm{H}$ 2.77, N 11.22\%; Found C 40.96, H 3.21, N 11.01\%.

Synthesis of complex 9. Complex $8(50 \mathrm{mg}, 80 \mu \mathrm{mol})$ was dissolved in $\mathrm{MeCN}(8 \mathrm{~mL})$ and $\mathrm{AgPF}_{6}(45 \mathrm{mg}, 0.18 \mathrm{mmol}$ ) was added. The reaction mixture was stirred at reflux temperature for $20 \mathrm{~h}$. After cooling, all volatiles were evaporated and the residue was dissolved in a minimum amount of $\mathrm{H}_{2} \mathrm{O}$ and extracted with $\mathrm{CH}_{2} \mathrm{Cl}_{2}(3 \times 5 \mathrm{~mL})$. The combined organic layers were washed with $\mathrm{H}_{2} \mathrm{O}(5 \mathrm{~mL})$ and dried over $\mathrm{Mg}_{2} \mathrm{SO}_{4}$. The solution was poured into pentane $(30 \mathrm{~mL})$ and the formed precipitate was filtered and washed with pentane. After drying in vacuo complex 9 was obtained as an off-white solid (45 mg, 33\%). X-ray quality crystals were grown by slow diffusion of $\mathrm{Et}_{2} \mathrm{O}$ into a $\mathrm{MeCN}$ solution of complex 9 at $-20{ }^{\circ} \mathrm{C}$. Elem. Anal. Calcd for $\mathrm{C}_{21} \mathrm{H}_{23} \mathrm{~F}_{12} \mathrm{~N}_{7} \mathrm{P}_{2} \mathrm{Ru}$ (764.45): C 32.99, H 3.03, N 12.83\%; Found: $\mathrm{C}$ 33.23, H 2.91, N 13.04. ${ }^{1} \mathrm{H}$ NMR (300 MHz, $\left.\mathrm{CDCl}_{3}\right): \delta=8.97\left(\mathrm{dd},{ }^{3} J_{\mathrm{HH}}=5.8 \mathrm{~Hz},{ }^{4} J_{\mathrm{HH}}=0.9\right.$ $\left.\mathrm{Hz}, 1 \mathrm{H}, \mathrm{H}_{\mathrm{py}}\right), 8.27-8.13\left(\mathrm{~m}, 3 \mathrm{H}, \mathrm{H}_{\mathrm{Ar}}+2 \mathrm{H}_{\mathrm{py}}\right), 7.81-7.73\left(\mathrm{~m}, 1 \mathrm{H}, \mathrm{H}_{\mathrm{Ar}}\right), 7.64-7.51(\mathrm{~m}, 2 \mathrm{H}$, $\left.\mathrm{H}_{\mathrm{Ar}}\right), 7.47\left(\mathrm{ddd},{ }^{3} J_{\mathrm{HH}}=7.2 \mathrm{~Hz},{ }^{3} J_{\mathrm{HH}}=5.8 \mathrm{~Hz},{ }^{3} J_{\mathrm{HH}}=1.3 \mathrm{~Hz}, 1 \mathrm{H}, \mathrm{H}_{\mathrm{py}}\right), 4.26\left(\mathrm{~s}, 3 \mathrm{H}, \mathrm{N}-\mathrm{CH}_{3}\right)$, $2.56\left(\mathrm{~s}, 3 \mathrm{H}, \mathrm{NC}-\mathrm{CH}_{3}\right), 2.07\left(\mathrm{~s}, 6 \mathrm{H}, \mathrm{NC}-\mathrm{CH}_{3}\right), 1.96\left(\mathrm{~s}, 3 \mathrm{H}, \mathrm{NC}-\mathrm{CH}_{3}\right) .{ }^{13} \mathrm{C}\left\{{ }^{1} \mathrm{H}\right\} \mathrm{NMR}(100$ $\left.\mathrm{MHz}, \mathrm{CDCl}_{3}\right): \delta=204.0(\mathrm{C}-\mathrm{Ru}), 156.9\left(C_{\mathrm{py}}-\mathrm{C}\right), 154.4\left(\mathrm{C}_{\mathrm{py}}-\mathrm{H}\right), 141.9\left(\mathrm{C}_{\mathrm{py}}-\mathrm{H}\right), 138.2\left(\mathrm{C}_{\mathrm{Ar}}-\right.$ $\mathrm{N}), 132.7\left(\mathrm{C}_{\mathrm{Ar}}-\mathrm{N}\right), 127.7(\mathrm{NCMe}), 126.1\left(\mathrm{C}_{\mathrm{Ar}}-\mathrm{H}\right), 123.0\left(\mathrm{C}_{\mathrm{Ar}}-\mathrm{H}\right), 125.1(\mathrm{NCMe}), 123.0\left(\mathrm{C}_{\mathrm{py}}-\right.$ $\mathrm{H}), 118.7(\mathrm{NCMe}), 113.7\left(\mathrm{C}_{\mathrm{py}}-\mathrm{H}\right), 112.9\left(\mathrm{C}_{\mathrm{Ar}}-\mathrm{H}\right), 112.3\left(\mathrm{C}_{\mathrm{Ar}}-\mathrm{H}\right), 35.3\left(\mathrm{~N}-\mathrm{CH}_{3}\right), 4.8(\mathrm{NC}-$ $\left.\mathrm{CH}_{3}\right), 4.4\left(\mathrm{NC}-\mathrm{CH}_{3}\right), 1.4\left(\mathrm{NC}-\mathrm{CH}_{3}\right)$. Elem. Anal. Calcd for $\mathrm{C}_{21} \mathrm{H}_{23} \mathrm{~F}_{12} \mathrm{~N}_{7} \mathrm{P}_{2} \mathrm{Ru}$ (764.45): C 32.99, H 3.03, N 12.83\%; Found C 33.23, H 2.91, N 13.04\%. 
Crystal Structure Determinations. Suitable single crystals were mounted on a StoeMark IIImaging Plate Diffractometer System (Stoe \& Cie, 2002) equipped with a graphitemonochromator. Data collection was performed using Mo-K $\alpha$ radiation $(\lambda=0.71073 \AA)$ with a nominal crystal to detector distance of $135 \mathrm{~mm}$. All structures were solved by direct methods using SHELXS-97 and refined by full matrix least-squares on $F^{2}$ for all data using SHELXL-97. ${ }^{[39]}$ The hydrogen atoms were included in calculated positions and treated as riding atoms using SHELXL-97 default parameters. Anisotropic thermal displacement parameters were used for all non-hydrogen atoms. Four independent molecules and eight disordered $\mathrm{PF}_{6}{ }^{-}$anions are present in the unit-cell of 9 . Attempts to resolve the disorder of the $\mathrm{PF}_{6}^{-}$ions and solvent molecules using the SQUEEZE routine ${ }^{[40]}$ were unsuccessful due to the low quality of the data. Further crystallographic details are compiled in the supporting information. CCDC numbers 949564 (2), 949565 (6), and 949566 (10) contain the supplementary crystallographic data for this paper. These data can be obtained free of charge from the Cambridge Crystallographic Data Centre via www.ccdc.cam.ac.uk/data_request/cif.

\section{Acknowledgements}

We thank P. Belser for fruitful discussions. This work was financially supported by a Marie Curie Intra-European Fellowship (PIEF-221323) and by the Eureopean Research Council (ERC StG-208561).

\section{Supporting Information}

Crystallographic details, ORTEP of complex 2, electrochemical details of complexes 5-10.

\section{References}

[1] (a) M. Irie, Chem. Rev. 2000, 100, 1683-1684. (b) S. A. Wolf, D. D. Awschalom, R. A. Buhrman, J. M. Daughton, S. von Molnar, M. L. Roukes, A. Y. Chtchelkanova, D. M. Treger, Science 2001, 294, 1488-1495. (c) J. E. Green, J. W. Choi, A. Boukai, Y. Bunimovich, . Johnston-Halperin, E. Delonno, Y. Luo, B. A. Sheriff, K. Xu, Y. S. Shin, H.-R. Tseng, J. F. Stoddart, J. R. Heath, Nature 2007, 445, 414-417. (d) J. P. Sauvage (Ed.) Molecular Machines and Motors, Springer (Berlin, Germany), 2001. (e) B. L. Feringa, W. R. Browne (Eds.) Molecular Switches, Wiley-VCH (Weinheim, Germany), 2011.

[2] (a) R. A. Bissell, E. Cordova, A. E. Kaifer, J. F. Stoddart, Nature 1994, 369, 133-137. (b) D. Astruc, Acc. Chem. Res. 1997, 30, 383-391. (c) J. M. Tour, Acc. Chem. Res. 2000, 33, 
791-804. (d) D. N. Hendrickson, C. G. Pierpont, Top. Curr. Chem. 2004, 234, 63-95. (e) W. E. Geiger, Organometallics 2011, 30, 28-31.

[3] (a) O. Kahn, C. J. Martinez, Science, 1998, 279, 44-48. (b) J.-F. Létard, Top. Curr. Chem. 2004, 235, 221-249. (c) M. A. Halcrow, Chem. Soc. Rev. 2011, 40, 4119. (d) S. Venkataramani, U. Jana, M. Dommaschk, F. D. Sönnichsen, F. Tuczek, R. Herges, Science 2011, 331, 445-448.

[4] (a) S. Shinkai, T. Nakaji, Y. Nishida, T. Ogawa, O. Manabe, J. Am. Chem. Soc. 1980, 102, 5860-5865. (b) M. Irie, Chem. Rev. 2000, 100, 1685-1716. (c) B. L. Feringa, R: A. van Delden, N. Koumura, E. M. Geertsema, Chem. Rev. 2000, 100, 1789-1816. (d) V. Balzani, A. Credi, M. Venturi, Proc. Natl. Acad. Sci. USA, 2002, 99, 4814. (e) A. P. de Silva, M. R. James, B. O. F. McKinney, D. A. Pears, S. M. Weir, Nature Mater. 2006, 5, 787.

[5] (a) C. Creutz, H. Taube, J. Am. Chem. Soc. 1969, 91, 3988-3989. (b) N. S. Hush, Prog. Inorg. Chem. 1967, 8, 391-444. (c) H. Taube, Angew. Chem. Int. Ed. Engl. 1984, 23, 329. (d) N. S. Hush, Coord. Chem. Rev. 1985, 64, 135-157. (e) C. Creutz, M. D. Newton, N. Sutin, J. Photochem. Photobiol. A, 1994, 82, 47. (f) B. S. Brunschwig, C. Creutz, N. Sutin, Chem. Soc. Rev. 2002, 31, 168.

[6] (a) W. Kaim, A. Klein, M. Glöckle, Acc. Chem. Res. 2000, 33, 755. (b) J.-P. Launay, Chem. Soc. Rev. 2001, 30, 386. (c) D. M. D'Alessandro, F. R. Keene, Chem. Rev. 2006, 106, 2270. (d) W. Kaim, G. K. Lahiri, Angew. Chem. Int. Ed. 2007, 46, 1778. (e) M. H. Chisholm, N. J. Patmore, Acc. Chem. Res. 2007, 40, 19. (f) J. Hankache, O. S. Wenger, Chem. Rev. 2011, 111, 5138 .

[7] (a) Aviram, A. Ratner, M. Chem. Phys. Lett. 1974, 29, 277. (b) Joachim, C. Gimzewski, J. K. Aviram, A. Nature 2000, 408, 541. (c) M. Mayor, H. B. Weber, Angew. Chem. Int. Ed. 2004, 43, 2882-2884. (d) Lindsay, S. M. Ratner, M. A. Adv. Mater. 2007, 19, 23.

[8] (a) I. Manners, Chem. Rev. 1999, 99, 1515. B. (b) J. Holliday, T. M. Swager, Chem. Commun. 2005, 23. (c) J. Roncali, J. Mater. Chem. 1999, 9, 1875. (d) M. S. Gudiksen, L. J. Lauhon, J. Wang, D. C. Smith, C. M. Lieber, Nature 2002, 415, 617-620. (e) C. Moorlag, B. C. Sih, T. L. Stott, M. O. Wolf, J. Mater. Chem. 2005, 15, 33. (f) K. A. Williams, A. J. Boydston, C. W. Bielawski, Chem. Soc. Rev. 2007, 36, 729-744.

[9] P. Aguirre-Etcheverry, D. O’Hare, Chem. Rev. 2010, 110, 4839-4864.

[10] For selected representative examples, see: (a) C. Patoux, J.-P. Launay, M. Beley, S. Chodorowski-Kimmes, J.-P. Collin, S. James, J.-P. Sauvage, J. Am. Chem. Soc. 1998, 120, 3717. (b) P. Steenwinkel, D. M. Grove, N. Veldman, A. L. Spek, G. van Koten, Organometallics 1998, 17, 5647. (c) M. D. Ward, J. Chem. Educ. 2001, 78, 321. (d) S. Fraysse, C. Coudret, J.-P. Launay, J. Am. Chem. Soc. 2003, 125, 5880. (e) L. Cola, (Ed.), Top. Curr. Chem. 2005, 257. (f) A. Nitzan, M. A. Ratner, Science 2007, 300, 1384. (g) O. S. Wenger, Coord. Chem. Rev. 2009, 253, 1439. (h) N. Chanda, B. Sarkar, F. Jan, W. Kaim, G. K. Lahiri, Dalton Trans. 2003, 3550-3555. 
[11] (a) N. Le Narvor, L. Toupet, C. Lapinte, J. Am. Chem. Soc. 1995, 117, 7129-7138. (b) S. Barlow, D. O'Hare, Chem. Rev. 1997, 97, 637-670. (c) F. Paul, C. Lapinte, Coord. Chem. Rev. 1998, 178-180, 431-509.S. (d) Szafert, J. A. Gladysz, Chem. Rev. 2003, 103, 4175. (e) D. A. Valyaev, O. S. Semeikin, N. A. Ustynyuk, Coord. Chem. Rev. 2004, 248, 1679-1692.

[12] (a) R. Breslow, J. Am. Chem. Soc. 1958, 80, 3719-3736. (b) H. W. Wanzlick, H. J. Schönherr, Angew. Chem. Int. Ed. 1968, 7, 141. (c) K. Öfele, J. Organomet. Chem. 1968, 12, P42-P43. A. (d) A. Igau, H. Grützmacher, A. Baceiredo, G. Bertrand, J. Am. Chem. Soc. 1988, 110, 6463-6466. (e) A. J. Arduengo, R. L. Harlow, M. Kline, J. Am. Chem. Soc. 1991, $113,361-363$.

[13] (a) D. Bourissou, O. Guerret, F. P. Gabbaï, G. Bertrand, Chem. Rev. 2000, 100, 39-92. (b) F. E. Hahn, M. C. Jahnke, Angew. Chem. Int. Ed. 2008, 47, 3122-3172. (c) M. Poyatos, J. A. Mata, E. Peris, Chem. Rev. 2009, 109, 3677-3707. (d) M. Melaimi, M. Soleilhavoup, G. Bertrand, Angew. Chem. Int. Ed. 2010, 49, 8810-8849.

[14] For representative work see: (a) D. S. McGuinness, N. Saendig, B. F. Yates, K. J. Cavell, J. Am. Chem. Soc. 2001, 123, 4029. (b) A. D. D. Tulloch, A. A. Danopoulos, S. Kleinhenz, M. E. Light, M. B. Hursthouse, G. Eastham, Organometallics 2001, 20, 2027. (c) X. L. Hu, I. Castro-Rodriguez, K. Olsen, K. Meyer, Organometallics 2004, 23, 755. (d) D. Nemcsok, K. Wichmann, G. Frenking Organometallics 2004, 23, 3640. (e) L. Gagliardi, C. J. Cramer, Inorg. Chem. 2006, 45, 9442. (f) S. Saravankumar, A. I. Oprea, M. K. Kindermann, P. G. Jones, J. Heinicke, Chem. Eur. J. 2006, 12, 3143. (g) W. A. Herrmann, J. Schütz, G. D. Frey, E. Herdtweck, Organometallics 2006, 25, 2437. (h) L. Mercs, G. Labat, A. Neels, A. Ehlers, M. Albrecht, Organometallics 2006, 25, 5648. (i) D. M. Khramov, V. M. Lynch, C. W. Bielawski, Organometallics 2007, 26, 6042. (j) E. F. Penka, C. W. Schläpfer, M. Atanasov, M. Albrecht, C. Daul, J. Organomet. Chem. 2007, 692, 5709. (k) U. Radius, F. M. Bickelhaupt, Organometallics 2008, 27, 3410. (l) Khramov, D. M. Rosen, E. L. Er, J. A. V. Vu, P. D. Lynch, V. M. Bielawski, C. W. Tetrahedron 2008, 64, 6853-6862. (m) H. Jacobsen, A. Correa, A. Poater, C. Costabile, L. Cavallo, Coord. Chem. Rev. 2009, 253, 687.

[15] (a) O. Guerret, S. Solé, H. Gornitzka, M. Teichert, G. Trinquier, G. Bertrand, J. Am. Chem. Soc. 1997, 119, 6668-6669. (b) D. M. Khramov, A. J. Boydston, C. W. Bielawski, Angew. Chem. Int. Ed. 2006, 45, 6186-6189. (c) A. J. Boydston, C. W. Bielawski, Dalton Trans. 2006, 4073-4077. (d) A. Zanardi, R. Corberan, J. A. Mata, E. Peris, Organometallics 2008, 27, 3570-3576. (e) L. Mercs, A. Neels, H. Stoeckli-Evans, M. Albrecht, Dalton Trans. 2009, 7168-7178. (f) A Zanardi, J. A. Mata, E. Peris, J. Am. Chem. Soc. 2009, 131, 1453114537. (g) K. A. Williams, C. W. Bielawski, Chem. Commun. 2010, 46, 5166. (h) L. Mercs, A. Neels, H. Stoeckli-Evans, M. Albrecht, Inorg. Chem. 2011, 50, 8188-8196. (i) A. Prades, M. Poyatos, J. A. Mata, E. Peris, Angew. Chem. Int. Ed. 2011, 50, 7666-7669. (j) M. Schmidtendorf, T. Pape, F. E. Hahn, Angew. Chem. Int. Ed. 2012, 51, 2195-2198. (k) A. Prades, E. Peris, M. Alcarazo, Organometallics 2012, 31, 4623-4626. (1) M. T. Zamora, M. J. Ferguson, R. McDonald, M. Cowie, Organometallics 2012, 31, 5463-5477. (m) S. Sabater, J. A. Mata, E. Peris, Organometallics 2012, 31, 6450-6456. (n) R. Maity, H. Koppetz, A. Hepp, F. E. Hahn, J. Am. Chem. Soc. 2013, 135, 4966-4969. (o) R. Maity, A. Rit, C. Schulte to 
Brinke, C. G. Daniliuc, F. E. Hahn, Chem. Commun. 2013, 49, 1011-1013. (p) S. Gonell, M. Poyatos, J. A. Mata, E. Peris, Angew. Chem. Int. Ed. 2013, 52, 7009-7013.

[16] D. G. Gusev, E. Peris, Dalton Trans. 2013, 42, 7359-7364.

[17] A. G. Tennyson, E. L. Rosen, M. S. Collins, V. M. Lynch, C. W. Bielawski, Inorg. Chem. 2009, 48, 6924-6933.

[18] L. Mercs, A. Neels, M. Albrecht, Dalton Trans. 2008, 5570-5576.

[19] O. Schuster, L. Mercs, M. Albrecht, Chimia 2010, 64, 184-187.

[20] (a) A. Juris, V. Balzani, F. Barigelletti, S. Campagna, P. Belser, A. von Zelewsky, Coord. Chem. Rev. 1988, 84, 85. (b) C. Kaes, A. Katz, M. W. Hosseini, Chem. Rev. 2000, 100, 3553-3590 (c) Constable, E. C. Chem. Soc. Rev. 2007, 36, 246. (d) M. D. Ward, Chem. Commun. 2009, 4487.

[21] A. J. Boydston, P. D. Vu, O. L. Dykhno, V. Chang, A. R. Wyatt, A. S. Stockett, E. T. Ritschdorff, J. B. Shear, C. W. Bielawski, J. Am. Chem. Soc. 2008, 130, 3143-3156.

[22] (a) A. Prades, M. Viciano, M. Sanau, E. Peris, Organometallics 2008, 27, 4254-4259. (b) C. Gandolfi, M. Heckenroth, A. Neels, G. Laurenczy, M. Albrecht, Organometallics. 2009, 28, 5112-5121. (c) L. Bernet, R. Lalrempuia, W. Ghattas, H. Mueller-Bunz, L. Viagara, A. Llobet, M. Albrecht, Chem. Commun., 2011, 47, 8058-8060.

[23] (a) H. M. J. Wang, I. J. B. Lin, Organometallics 1998, 17, 972-975. (b) I. J. B. Lin, C. S. Vasam, Comments Inorg. Chem. 2004, 25, 75-129. (c) J. C. Garrison, W. J. Youngs, Chem. Rev. 2005, 105, 3978-4008.

[24] (a) J. A. Mata, A. R. Chianese, J. R. Miecznikowski, M. Poyatos, E. Peris, J. W. Faller, R. H. Crabtree, Organometallics 2004, 23, 1253-1263. (b) T. Zamora, M. J. Ferguson, M. Cowie, Organometallics 2012, 31, 5384-5395.

[25] (a) R. Le Lagadec, L. Rubio, L. Alexandrova, R. A. Toscano, E. V. Ivanova, R. Meskys, V. Laurinavicius, M. Pfeffer, A. D. Ryabov, J. Organomet. Chem. 2004, 689, 4820 4832. (b) D. Kuang, S. Ito, B. Wenger, C. Klein, J.-E. Moser, R. Humphry-Baker, S. M. Zakeeruddin, M. Grätzel, J. Am. Chem. Soc. 2006, 128, 4146-4154. (c) W. Ghattas, H. Mueller-Bunz, M. Albrecht, Organometallics, 2010, 29, 6782-6789. (d) H.-S. Chen, W.-C. Chang, C. Su, T.-Y. Li, N.-M. Hsu, Y. S. Tingare, C.-Y. Li, J.-H. Shie, W.-R. Li, Dalton Trans. 2011, 40, 6765-6770. (e) V. Leigh, W. Ghattas, R. Lalrempuia, H. Mueller-Bunz, M. T. Pryce, M. Albrecht, Inorg. Chem., 2013, 52, 5395-5402.

[26] (a) A. A. D. Tulloch, A. A. Danopoulos, G. J. Tizzard, S. J. Coles, M. B. Hursthouse, R. S. Hay-Motherwell, W. B. Motherwell, Chem. Commun. 2001, 1270-1271. (b) J. A. Loch, M. Albrecht, E. Peris, J. Mata, J. W. Faller, R. H. Crabtree, Organometallics 2002, 21, 700706. (c) V. Khlebnikov, A. Meduri, H. Mueller-Bunz, T. Montini, P. Fornasiero, E. Zangrando, B. Milani, M. Albrecht, Organometallics 2012, 31, 976-986. 
[27] For example, the torsion angle between the vectors of the MeCN ligands trans to the carbene, defined by the two least-square planes containing Ru1, N23, N43, N53, and containing Ru1a, N23a, N43a, and N53a, respectively, is $38.84^{\circ}$ and thus deviates substantially from an ideally linear geometry (with torsion angle $0^{\circ}$ ).

[28] (a) T. W. Smith, J. E. Kuder, D. Wychick, J. Polym. Sci. Polym. Chem. Ed. 1976, 14, 2433-2448. (b) J. B. Flanagan, S. Margel, A. J. Bard, F. C. Anson, J. Am. Chem. Soc. 1978, $100,4248-4253$.

[29] M. B. Robin, P. Day, Adv. Inorg. Radiochem. 1968, 10, 247-422.

[30] M. Krejcik, M. Danek, F. Hartl, J. Electroanal. Chem 1991, 317, 179-187.

[31] D. M. D’Alessandro, F. R. Keene, Dalton Trans. 2004, 3950.

[32] For related borderline class II/III examples, see: (a) K. D. Demadis, C. M. Hartshorn, T. J. Meyer, Chem. Rev. 2001, 101, 2655. (b) B. J. Lear, S. D. Glover, J. C. Salsman, C. H. Londergan, C. P. Kubiak, J. Am. Chem. Soc. 2007, 129, 12772. (c) M. Koley, B. Sarkar, S. Ghumaan, E. Bulak, J. Fiedler, W. Kaim, G. K. Lahiri, Inorg. Chem. 2007, 46, 3736-3742. (d) T. Kurahashi, H. Fujii, J. Am. Chem. Soc. 2011, 133, 8307. (e) S. D. Glover, C. P. Kubiak, J. Am. Chem. Soc. 2011, 133, 8721. (f) W.-W. Yang, J. Yao, Y.-W. Zhong, Organometallics 2012, 31, 1035-1041.

[33] A. B. P. Lever, Inorg. Chem. 1990, 29, 1271-1285.

[34] W. Kaim, J. Fiedler, Chem. Soc. Rev. 2009, 38, 3373.

[35] W. R. Browne, R. Hage, J. G. Vos, Coord. Chem. Rev. 2006, 250, 1653-1668.

[36] R. A. Marcus, Annu. Rev. Phys. Chem. 1964, 15, 155-196.

[37] S. Barlow, C. Risko, S.-J. Chung, N. M. Tucker, V. Coropceanu, S. C. Jones, Z. Levi, J.-L. Brédas, S. R. Marder, J. Am. Chem. Soc. 2005, 127, 16900-16911.

[38] N. G. Connelly, W. E. Geiger, Chem. Rev. 1996, 96, 877-910.

[39] G. M. Sheldrick, Acta Cryst. A 2007, 64, 112-122.

[40] A. L. Spek, Acta Cryst. D 2009, 65, 148-155. 


\section{Supporting Information}

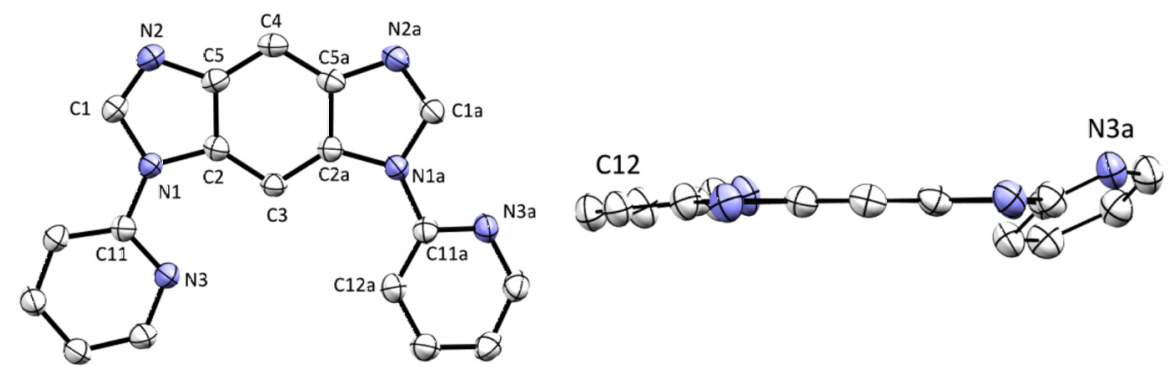

Figure S1a. ORTEP View of 2 (ellipsoids at the 50\% probability level). Hydrogen atoms have been omitted for clarity.

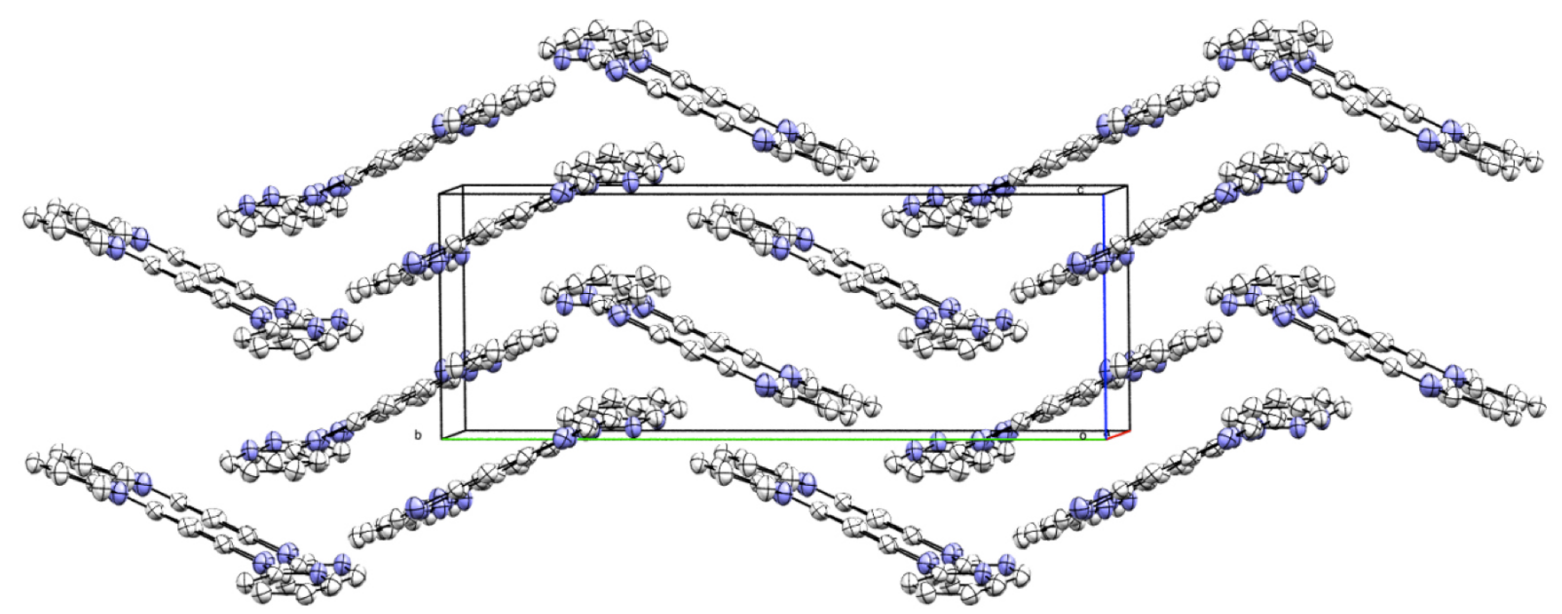

Figure S1b. Packing diagram of compound 2 seen along the a-axis (ellipsoids at the 50\% probability level). Hydrogen atoms have been omitted for clarity.

Table S1. Selected interatomic distances $(\AA)$ and angles $\left(^{\circ}\right)$ for compound 2.

\begin{tabular}{llll}
\hline $\mathrm{C} 1-\mathrm{N} 1$ & $1.3808(17)$ & $\mathrm{C} 5-\mathrm{C} 4$ & $1.388(2)$ \\
$\mathrm{C} 1 \mathrm{a}-\mathrm{N} 1 \mathrm{a}$ & $1.3787(17)$ & $\mathrm{C} 5 \mathrm{a}-\mathrm{C} 4$ & $1.386(2)$ \\
$\mathrm{C} 1-\mathrm{N} 2$ & $1.2968(19)$ & $\mathrm{N} 1-\mathrm{C} 11$ & $1.4150(17)$ \\
$\mathrm{C} 1 \mathrm{a}-\mathrm{N} 2 \mathrm{a}$ & $1.2983(19)$ & $\mathrm{N} 1 \mathrm{a}-\mathrm{C} 11 \mathrm{a}$ & $1.4172(17)$ \\
$\mathrm{N} 1-\mathrm{C} 2$ & $1.3976(17)$ & & \\
N1a-C2a & $1.4000(17)$ & $\mathrm{N} 1-\mathrm{C} 1-\mathrm{N} 2$ & $114.4(1)$ \\
$\mathrm{N} 2-\mathrm{C} 5$ & $1.3965(18)$ & $\mathrm{N} 1 \mathrm{a}-\mathrm{C} 1 \mathrm{a}-\mathrm{N} 2 \mathrm{a}$ & $114.7(1)$ \\
$\mathrm{N} 2 \mathrm{a}-\mathrm{C} 5 \mathrm{a}$ & $1.4107(19)$ & $\mathrm{C} 1-\mathrm{N} 1-\mathrm{C} 11$ & $124.3(1)$ \\
$\mathrm{C} 2-\mathrm{C} 3$ & $1.3879(18)$ & $\mathrm{C} 1 \mathrm{a}-\mathrm{N} 1 \mathrm{a}-\mathrm{C} 11 \mathrm{a}$ & $125.9(1)$ \\
$\mathrm{C} 2 \mathrm{a}-\mathrm{C} 3$ & $1.3852(19)$ & & \\
$\mathrm{C} 2-\mathrm{C} 5$ & $1.4136(18)$ & $\mathrm{C} 1 \ldots \mathrm{C} 1 \mathrm{a}$ & $6.449(2)$ \\
$\mathrm{C} 2 \mathrm{a}-\mathrm{C} 5 \mathrm{a}$ & $1.4107(19)$ & & \\
\hline
\end{tabular}




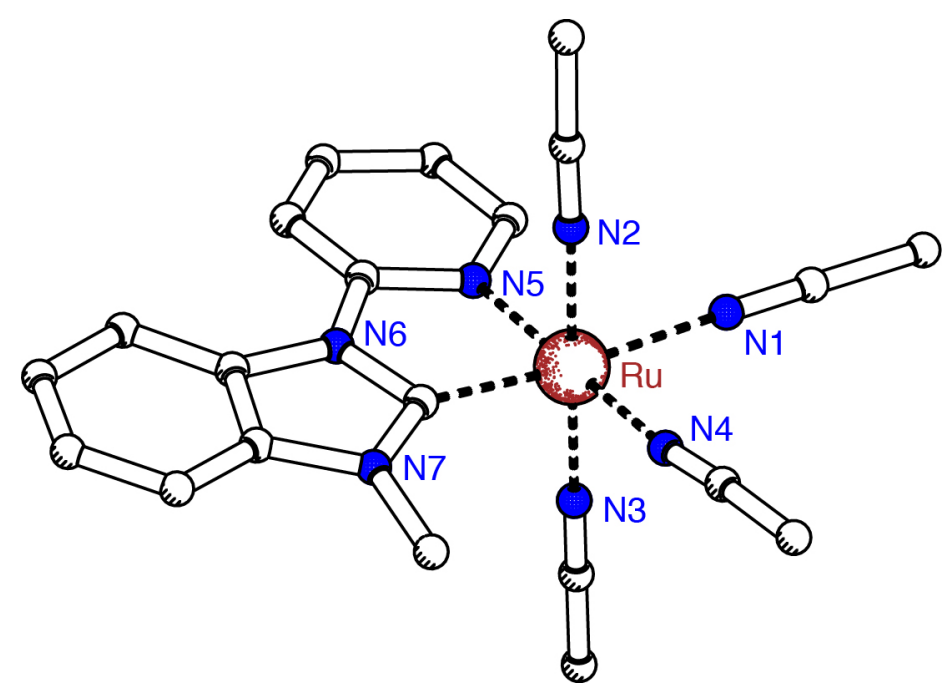

Figure S2. Pluton drawing of one of the four crystallographically independent complex cations of 9. Severe disorder in the anions could not be refined to acceptable levels, which prevents a full discussion of data. The bite angle of 9 is in the expected range ( $78.5^{\circ}$ in average over the four independent residues, cf Table 2 ). The bonds between the ruthenium center and the solvent ligands also follow the same trend as observed in 6, with the $\mathrm{MeCN}$ trans to the carbene markedly more distant from the $\mathrm{Ru}$ center than the other three $\mathrm{MeCN}$ ligands: $\mathrm{Ru}-\mathrm{C} 1$ 1.97; Ru-N1 2.12; Ru-N2 2.04; Ru-N3 2.03; Ru-N4 2.01; Ru-N5 2.06;
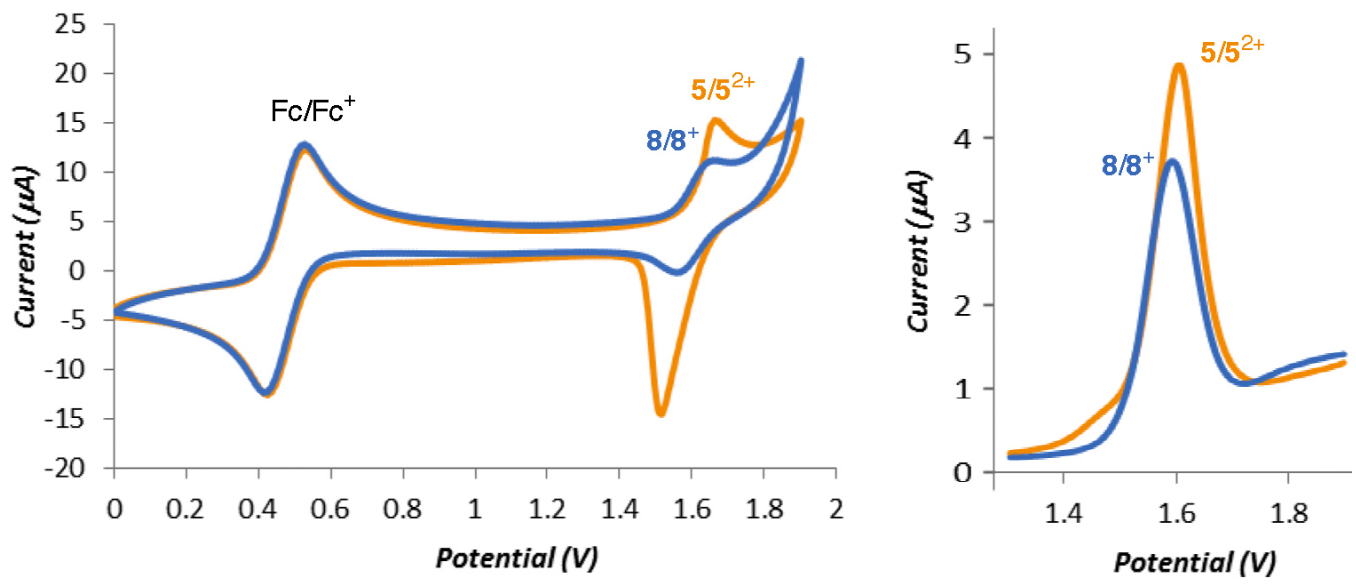

Figure S3.CV diagram (left) and DPV measurement (right) of complexes 5 and $\mathbf{8}$ (ca. $1 \mathrm{mM}$ ) in dry $\mathrm{CH}_{2} \mathrm{Cl}_{2} \mathrm{with}$ $0.1 \mathrm{M}\left[\mathrm{NBu}_{4}\right]\left[\mathrm{PF}_{6}\right]$ as supporting electrolyte at $100 \mathrm{mV} \mathrm{s}^{-1}$ scan rate; $\mathrm{Fc}^{+} / \mathrm{Fc}$ used as internal reference. 

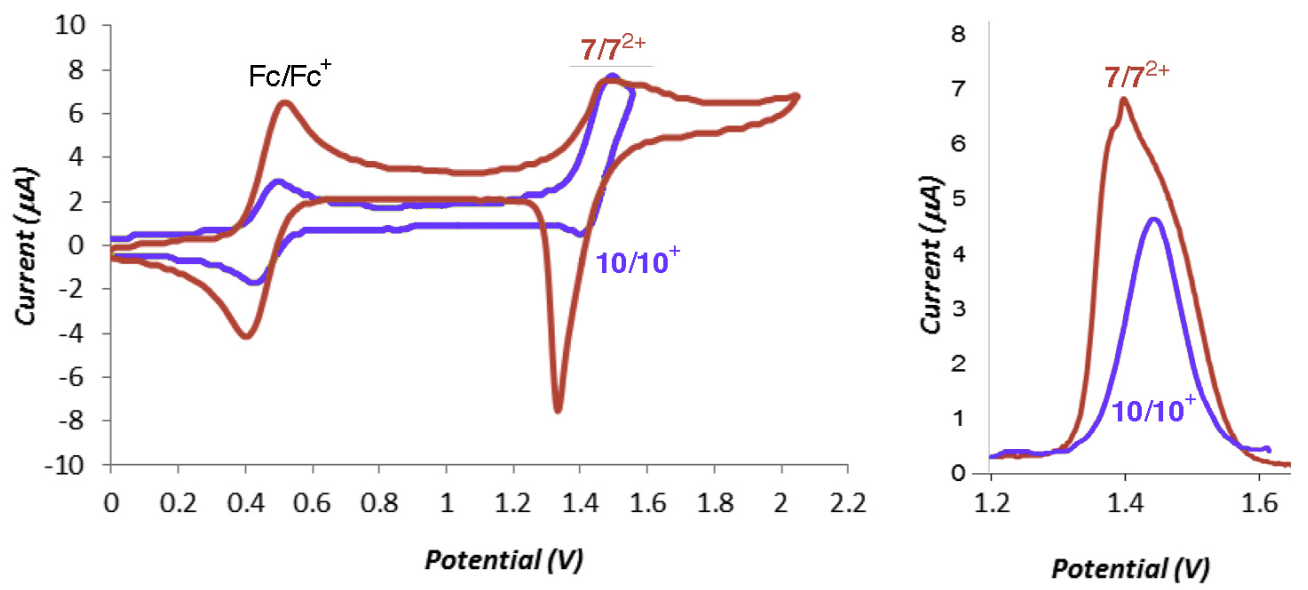

Figure S4. CV (left) and DPV (right) plot of complexes 7 and $\mathbf{1 0}$ (ca. $1 \mathrm{mM}$ ) in dry $\mathrm{CH}_{2} \mathrm{Cl}_{2}$ with $0.1 \mathrm{M}$ $\left[\mathrm{NBu}_{4}\right]\left[\mathrm{PF}_{6}\right]$ as supporting analyte, $50 \mathrm{mV} \mathrm{s}^{-1}$ scan rate $\left(\mathrm{Fc}^{+} / \mathrm{Fc}\right.$ used as internal standard, $\mathrm{E}_{1 / 2}\left(\mathrm{Fc} / \mathrm{Fc}^{+}\right)=0.41 \mathrm{~V}$ vs. SCE).

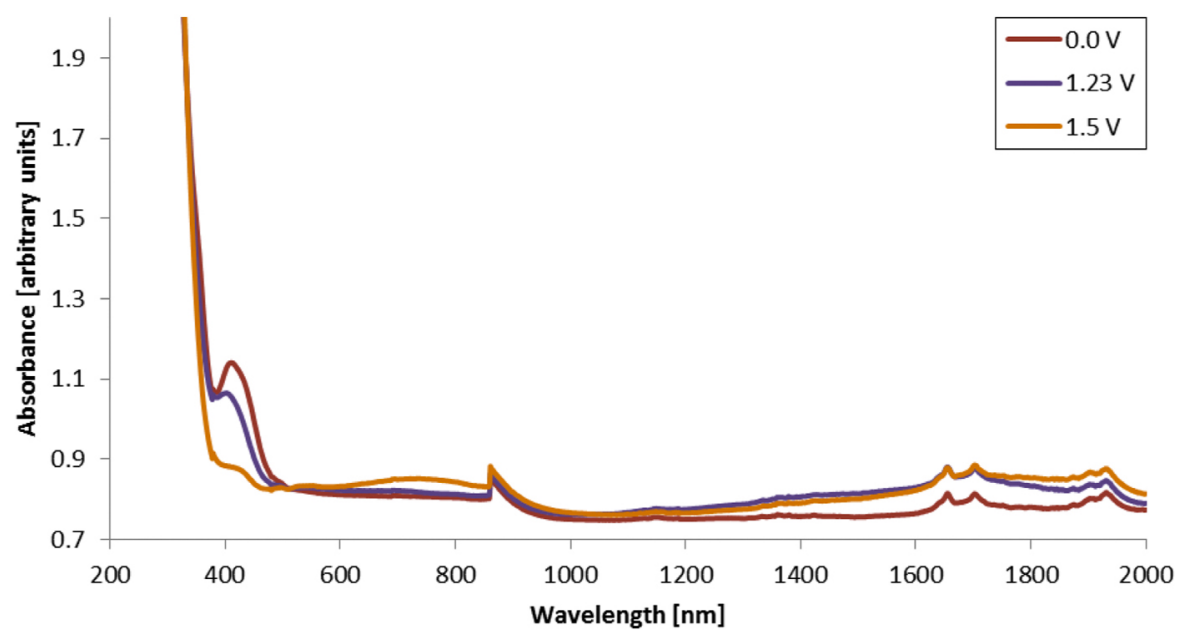

Figure S5. Absorption spectra of complexes 7 at $0.0 \mathrm{~V}, 7^{+}$at $+1.23 \mathrm{~V}$ and $7^{2+}$ at $+1.5 \mathrm{~V}\left(\mathrm{MeNO}_{2}\right.$ solution). 

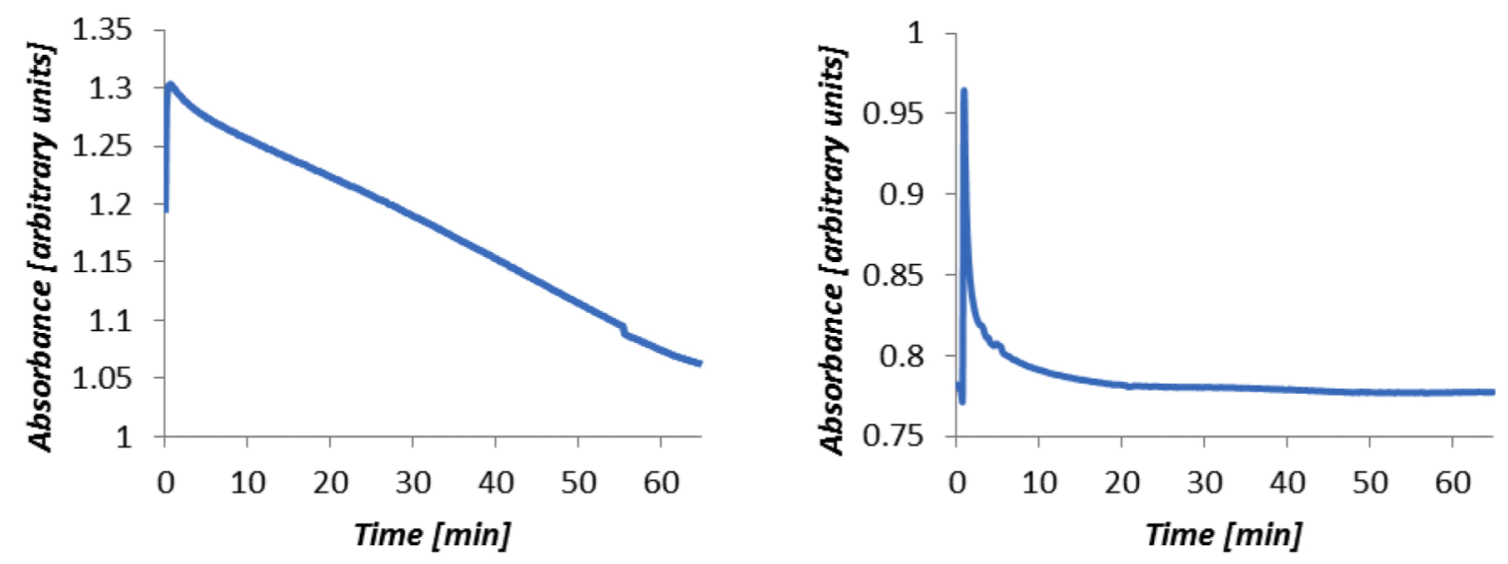

Figure S6. Stability tests: MV species $\mathbf{6}^{+}$at $1.46 \mathrm{~V}$ observed at $1590 \mathrm{~nm}$ (left). Fully oxidized $\mathbf{6}^{2+}$ species at 1.6 V observed at $820 \mathrm{~nm}$ (right).
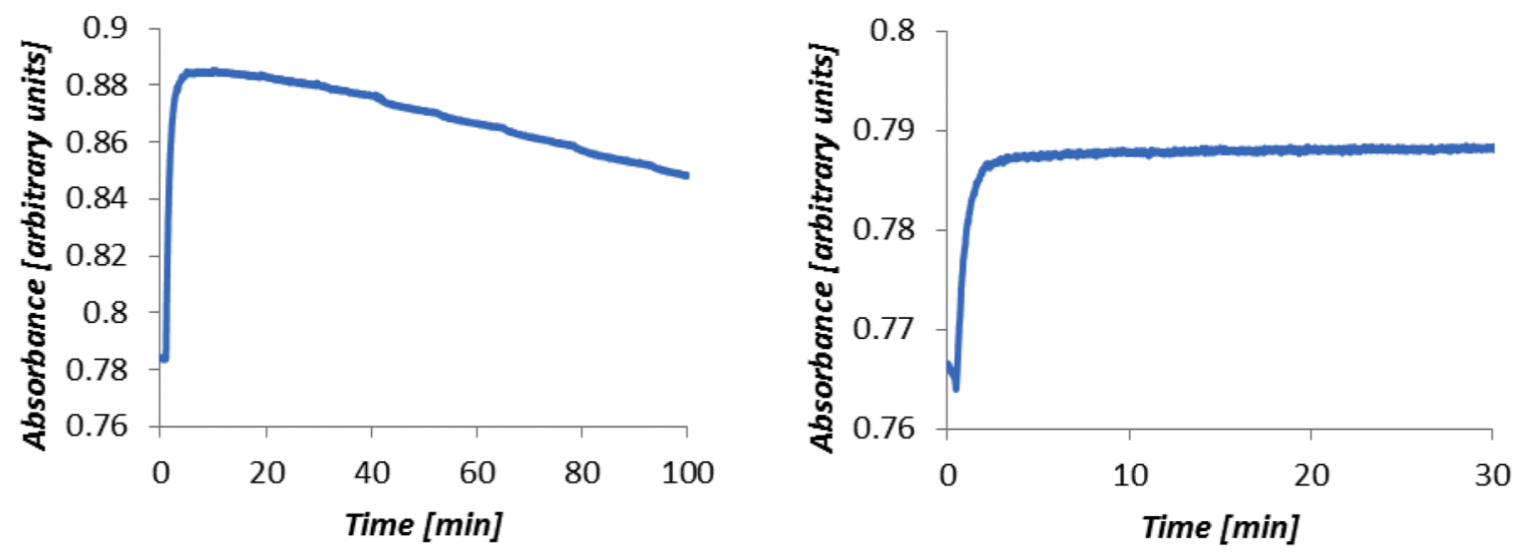

Figure S7. Stability tests: MV species $7^{+}$at $1.23 \mathrm{~V}$ observed at $1730 \mathrm{~nm}$ (left).Dication $7^{2+}$ at $1.5 \mathrm{~V}$ observed at $740 \mathrm{~nm}$ (right).
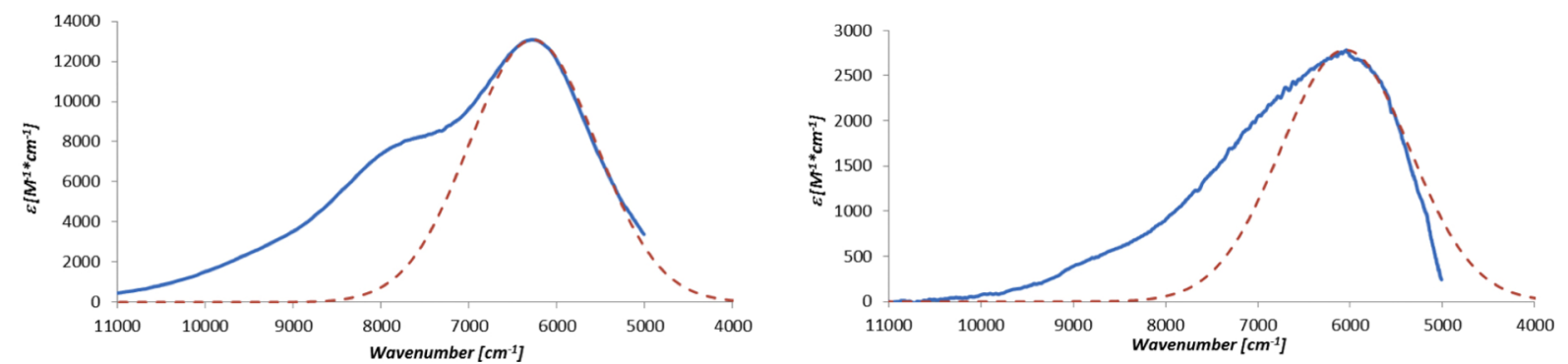

Figure S8. IVCT band of the mixed-valent species $6^{+}$(left) $7^{+}$(right; blue solid lines) and corresponding (symmetric) Gaussian fitting curves (red dashed lines). The poor fit demonstrates the asymmetric shape of the IVCT band. 
Table S2. Crystallographic data for compounds 2, 6, and $\mathbf{1 0 .}$

\begin{tabular}{|c|c|c|c|}
\hline & 2 & 6 & 10 \\
\hline $\begin{array}{l}\text { CCDC No. } \\
\text { mol formula }\end{array}$ & $\mathrm{C}_{18} \mathrm{H}_{12} \mathrm{~N}_{6}$ & $\mathrm{C}_{52} \mathrm{H}_{64} \mathrm{~F}_{24} \mathrm{~N}_{22} \mathrm{P}_{4} \mathrm{Ru}_{2}$ & $\mathrm{C}_{33} \mathrm{H}_{27} \mathrm{~F}_{12} \mathrm{~N}_{7} \mathrm{P}_{2} \mathrm{Ru}$ \\
\hline Crystal system & Monoclinic & Monoclinic & Triclinic \\
\hline Space group & $P 2_{1} / c$ & $P 2_{1} / c$ & $P_{-1}$ \\
\hline \multicolumn{4}{|l|}{ Unit cell } \\
\hline $\mathrm{a} / \AA$ & $9.2616(4)$ & $12.154(2)$ & $10.4632(9)$ \\
\hline $\mathrm{b} / \AA$ & $20.3317(6)$ & $28.597(6)$ & $12.4848(13)$ \\
\hline c $/ \AA$ & $7.5352(3)$ & $21.640(4)$ & $18.8260(15)$ \\
\hline$\alpha /{ }^{\circ}$ & 90 & 90 & $97.959(8)$ \\
\hline$\beta /{ }^{\circ}$ & $96.336(3)$ & $90.03(3)$ & $103.187(6)$ \\
\hline$\gamma /{ }^{\circ}$ & 90 & 90 & $114.396(6)$ \\
\hline Volume $/ \AA^{3}$ & $1410.24(9)$ & $7521(3)$ & $2104.2(3)$ \\
\hline $\mathrm{Z}$ & 4 & 4 & 2 \\
\hline $\mathrm{T} / \mathrm{K}$ & 200 & 100 & 150 \\
\hline$\mu / \mathrm{mm}^{-1}$ & 0.09 & 0.60 & 0.79 \\
\hline Abs. corr. & none & numerical & Numerical \\
\hline Total reflecns & 19196 & 13538 & 15954 \\
\hline Unique reflecns & 2652 & 13538 & 7309 \\
\hline parameters & 217 & 956 & 551 \\
\hline $\mathrm{R}_{1}^{\mathrm{a})}[\mathrm{I}>2 \sigma(\mathrm{I})]$ & 0.0388 & 0.0657 & 0.0585 \\
\hline $\mathrm{wR}_{2}{ }^{\mathrm{b})}[\mathrm{I}>2 \sigma(\mathrm{I})]$ & 0.1024 & 0.1556 & 0.1401 \\
\hline GOOF & 1.048 & 0.979 & 1.049 \\
\hline$\rho_{\text {fin }}(\max , \min ) / \mathrm{e} \AA^{-3}$ & $0.18,-0.20$ & $0.77,-0.87$ & $0.81,-0.69$ \\
\hline
\end{tabular}

